\title{
The relationship between adaptive management of social-ecological systems and law: a systematic review
}

\author{
Miguel F. Frohlich $^{1}$, Chris Jacobson $^{1}$, Pedro Fidelman $^{1,2}$ and Timothy F. Smith $^{1,3,4}$
}

\begin{abstract}
Adaptive management has been considered a valuable approach for managing social-ecological systems involving high levels of complexity and uncertainty. However, many obstacles still hamper its implementation. Law is often seen as a barrier for moving adaptive management beyond theory, although there has been no synthesis on the challenges of legal constraints or how to overcome them. We contribute to filling this knowledge gap by providing a systematic review of the peer-reviewed literature on the relationship between adaptive management and law in relation to social-ecological systems. We analyze how the scholarship defines the concept of adaptive management, identifies the legal barriers to adaptive management, and the legal strategies suggested for enabling this approach. Research efforts in this domain are still highly geographically concentrated in the United States of America, unveiling gaps concerning the analysis of other legal jurisdictions. Overall, our results show that more flexible legal frameworks can allow for adaptive management without undermining the role of law in providing stability to social interactions. Achieving this balance will likely require the reform of existing laws, regulations, and other legal instruments. Legal reforms can facilitate the emergence of adaptive governance, with the potential to support not only adaptive management implementation but also to make law itself more adaptive.
\end{abstract}

Key Words: adaptive governance; adaptive management; environmental management; law; legal institutions; legislation; systematic review

\section{INTRODUCTION}

Forty years after its first description by Holling (1978), adaptive management is still considered a valuable approach for dealing with dynamic social-ecological systems (Williams 2011, Westgate et al. 2013, Williams and Brown 2014, Garmestani and Allen 2015, Birgé et al. 2016). It has become increasingly popular among the scientific community, environmental management practitioners, and policy makers for improving decision-making processes involving high levels of complexity and uncertainty (Jacobson et al. 2009, Biber 2011, McFadden et al. 2011, Williams and Brown 2016).

Although the fundamentals of adaptive management have been exhaustively studied in the area of natural resource management (Holling and Sundstrom 2015), its effective practice is still timid (Lee 1999, Craig and Ruhl 2014, Lee 2014, Arnold 2015, Green et al. 2015). Failure of adaptive management implementation is often related to the design of institutions, e.g., the political structure, sets of norms, social values, and standards of behavior shaping human interactions, because they can be too conservative to allow for changes in management (Stankey et al. 2005, Gupta et al. 2010, Herrfahrdt-Pähle and Pahl-Wostl 2012).

Within this context, there has been increased efforts in recent decades to answer more specific research questions on how to eliminate constraints deriving from legal institutions and create harmony between adaptive management and law (Iles 1996, Doremus 2001, Karkkainen 2005, Ruhl 2005, Ruhl and Fischman 2010, Allen et al. 2011, Craig and Ruhl 2014, Garmestani and Allen 2014, Benson and Schultz 2015, Craig et al. 2017a). Recent contributions have questioned whether adaptive management may need to adapt to law (e.g., Biber 2013), while others have expanded this analysis to encompass the adaptive governance dimension (e.g., Cosens et al. 2017, Craig et al. 2017b, DeCaro et al. 2017a,b). There is a clear need to improve the knowledge of the impact of legal frameworks on adaptive management implementation (Benson 2012) and understand how adaptive management can be legally operationalized (Lee 2014, McDonald and Styles 2014).

We provide a systematic review with a main focus on the peerreviewed English language literature discussing the relationship between adaptive management and law. In particular, we seek to do the following: (i) present an overview of the main features of the literature sample; (ii) analyze definitions of adaptive management extracted from the literature sample; (iii) identify within this body of scholarship frequent cited legal barriers to adaptive management; and (iv) examine potential solutions scholars have been suggesting to overcome these legal barriers.

\section{METHODS}

Research and review articles in English language journals were obtained and assessed through a systematic review. This approach is common in several research fields, including environmental studies (Plummer et al. 2012a, Carter et al. 2015), and positive outcomes have been observed either with a quantitative or qualitative orientation (Steven et al. 2011, Plummer et al. 2012b, Ballantyne and Pickering 2015, Gallacher et al. 2016, Karpouzoglou et al. 2016). We adopted the Preferred Reporting Items for Systematic Reviews and Meta-Analyses (PRISMA) Four-Phase Flow Diagram (Moher et al. 2009) to search and select the literature (Fig. 1), drawing on examples of systematic reviews that have successfully used this structured process (Pickering and Byrne 2014, Ballantyne and Pickering 2015).

First, we created a set of keywords combining "adaptive management" and a group of legal terms (law OR legal OR legislation). For the purpose of this study, law comprises the body of enactments from (i) legislative branches, like constitutional provisions, statutes, and laws; (ii) executive branches, such as rules,

${ }^{1}$ Sustainability Research Centre, University of the Sunshine Coast, Queensland, Australia, ${ }^{2}$ Centre for Policy Futures, University of Queensland, Australia, ${ }^{3}$ Environmental Sustainability Research Centre, Brock University, Canada, ${ }^{4}$ SWEDESD, Uppsala University, Sweden 
Fig. 1. Flowchart outlining the protocol adopted in this systematic review based on the Preferred Reporting Items for Systematic Reviews and Meta-Analyses (PRISMA) Four-Phase Flow Diagram (Moher et al. 2009).

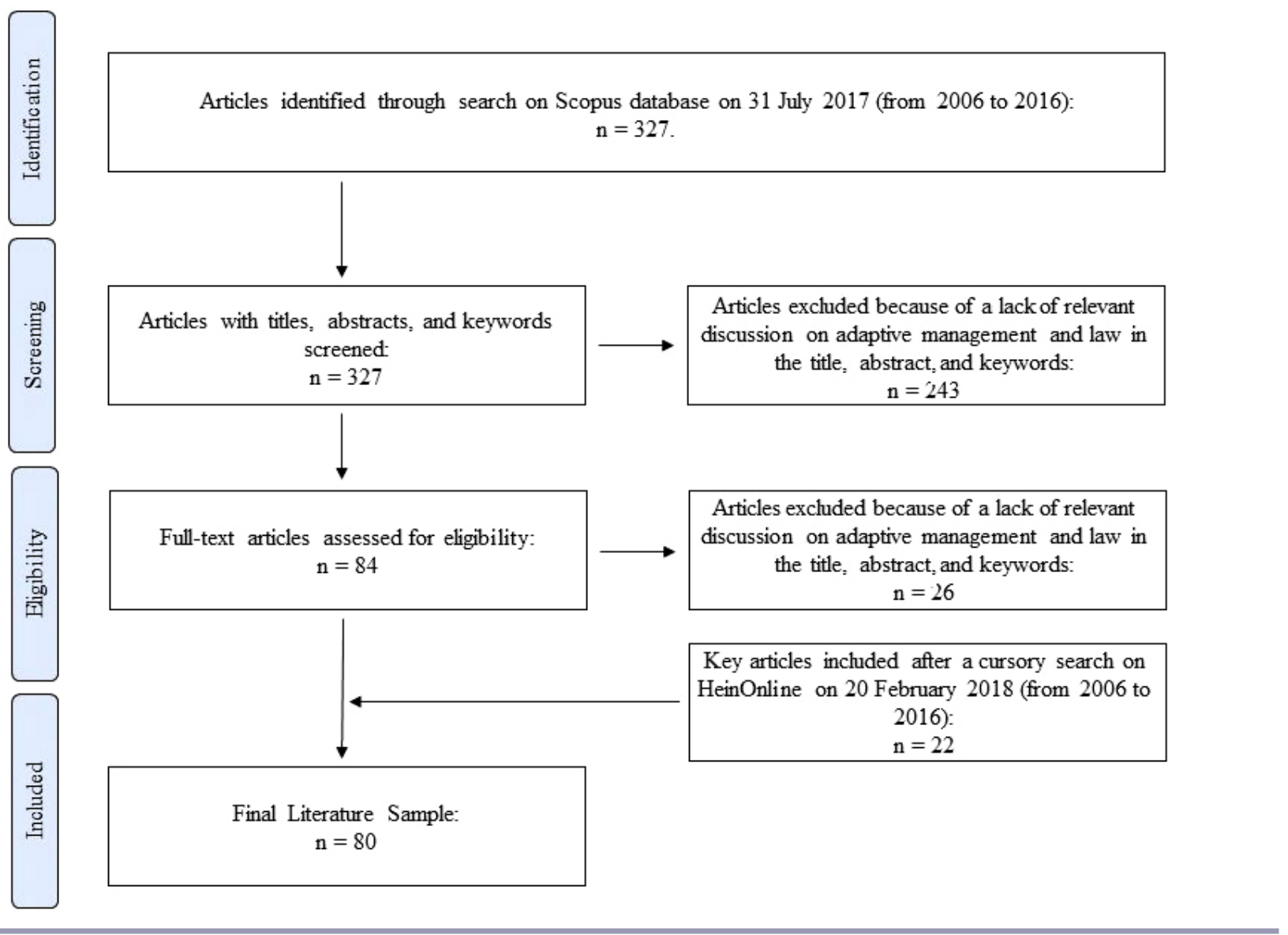

regulations, and normative instructions; and (iii) judicial branches, i.e., court decisions providing law enforcement or interpretation (Benson and Schultz 2015).

We ran a search for publications on Scopus, which is known as one of the most comprehensive peer-reviewed literature databases (Falagas et al. 2008, Carter et al. 2015). This source offers a broad coverage of the environmental studies, social sciences, and natural sciences fields (Moore et al. 2014). In addition, although our primary focus was on interdisciplinary peer-reviewed literature, we complemented our literature sample by conducting a cursory search for publications on HeinOnline, one of the world's most popular legal databases because of its vast collection of law journals (Justiss 2011, Gee 2013). Our final sample included 14 nonpeer-reviewed articles and reviews that reinforced the points made by the peer-reviewed literature or added new points. We highlighted in the text when a nonpeer-reviewed publication provided additional insights. We refer to additional points from such journals as "nonpeer-reviewed" in our analysis.

We acknowledge that our search and selection criteria may have excluded relevant publications, including peer-reviewed and nonpeer-reviewed literature available on other sources and, in particular, non-English research articles. The latter is especially worth noting because legal scholars generally have a tradition to publish in their native languages to target the audience familiar with the legal systems in which they are qualified. However, our synthesis still adds to the current body of research given the lack of any attempt at systematic reviews on this topic, and it may encourage further reviews on the relationship between adaptive management and law using different methods and sources, and within or across specific countries and legal jurisdictions.

To achieve our first research objective, a simple spreadsheet file (Appendix 1) was populated with information from selected publications to map their contextual aspects. The following categories were created: (i) authors and year of the publication; (ii) name of the journal; (iii) geographical context; (iv) main environmental sector or concern; and (v) adoption of interviews or surveys as one of the primary research methods. We included this latter category because we were particularly interested in understanding whether the literature considers the perceptions and contributions of stakeholders about adaptive management and law.

The geographical context of the publications was defined using countries where the case studies were located. If no specific case study was identified, countries used as a context for the theoretical research defined the geographical scope and, if none was applicable, such scope was defined by the countries to which the 
Table 1. Categorization of publications by environmental sector or concern, and use of interviews or surveys as a research method.

\begin{tabular}{|c|c|c|c|}
\hline Main environmental sector or concern & Description & $\begin{array}{c}\text { Articles } \\
\text { with interviews or } \\
\text { surveys }\end{array}$ & $\begin{array}{c}\text { Articles without } \\
\text { interviews or } \\
\text { surveys }\end{array}$ \\
\hline Forestry/Protected Areas & Management of forests and/or protected areas & 3 & 4 \\
\hline Water & Management of water bodies and/or resources & 4 & 14 \\
\hline Biodiversity & $\begin{array}{l}\text { Biodiversity conservation and/or management of wildlife, endangered and/ } \\
\text { or threatened species }\end{array}$ & 1 & 10 \\
\hline Fisheries & Management of fisheries and/or aquaculture & 1 & 1 \\
\hline Marine/Coastal & Management of marine areas, coasts, and/or estuaries. & 0 & 2 \\
\hline Multiple & $\begin{array}{l}\text { No specific sector or concern was identified, or multiple resources were } \\
\text { addressed without a discernible emphasis on one }\end{array}$ & 2 & 38 \\
\hline Total of Articles & & 11 & 69 \\
\hline
\end{tabular}

authors were affiliated. Publications having more than three countries were classified as multiple. The classification of the publications according to their environmental sector or concern included (i) forestry/protected areas; (ii) water; (iii) biodiversity; (iv) fisheries; and (vi) marine/coastal. If no specific sector or concern was identified, or more than one sector or concern was addressed without a special weight to any of them, the publication was included in the "multiple" category.

Retrieved publications were then organized within an EndNote library and submitted to content analysis through thematic coding using the NVivo software. Content analysis can be defined as a technique "for making systematic, credible, or valid and replicable inferences from texts and other forms of communication" (Drisko and Maschi 2015:8). The coding involved the identification and recording of passages from selected publications that were linked with a similar theoretical or descriptive idea (Gibbs 2007). Related passages were gathered and labeled under codes, i.e., the name that best represented the idea they shared in common.

Within NVivo, "nodes" are the containers where coded passages are stored, and this software enables the creation of tree nodes (Richards 1999), which were used to achieve our second, third, and fourth research objectives. To achieve our second research objective, we coded relevant passages where there was a clear intention to define adaptive management, interpret its characteristics, or explain its different forms. With respect to our third and fourth research objectives, we initially used open coding to create subcategories of nodes within the tree nodes. Subcategories were created when passages of selected publications presented or discussed potential or actual legal barriers - or solutions to overcome legal barriers - to adaptive management. When open coding reached a mature stage, we started to revisit the coded passages and regroup the data (axial coding process), in order to refine the organization of the most important patterns and concepts identified during the content analysis (Babbie 2007). Also, we created free nodes to store passages with tangential ideas, and we ran text search queries to identify the occurrences of words and phrases that could help confirming or complementing our findings. Although we recognize that the process of coding does not fully prevent biases (Carter et al. 2015), the adoption of this process helped to increase the reliability and validity, and consequently the accuracy of our analysis (Miles and Huberman 1994, Patton 2002).

\section{RESULTS AND DISCUSSION}

Overview of the literature sample

Although we reiterate that our review is not exhaustive, publication dates indicate that the discussion on the relationship between adaptive management and law is likely growing over recent years, especially when compared to the initial four-year period of our literature sample (Fig. 2). Table 1 categorizes the literature sample according to their main environmental sectors or concerns, and the adoption of interviews or surveys as a primary research method. Publications with a lack of emphasis on one specific environmental sector or concern, covering multiple resources, represented half of the sample. Within a singular resource context, water management was the most prominent (18 publications or approximately $22 \%$ of the sample). Conversely, fisheries and the management of marine areas, coasts, and estuaries were among the categories with fewer publications. Adaptive management in the context of integrated coastal management (ICM) has faced important challenges (Craig and Ruhl 2010, Jacobson et al. 2014), with few efforts related to its implementation (Smith and Lazarow 2006), and limited research on the identification of crucial mechanisms for its success (Smith and Smith 2006). Although we recognize that publications may have been excluded because of our search and selection criteria, the results of our systematic review indicate that, if framed within underexplored environmental management contexts, e.g., ICM, future contributions to the existing body of literature may potentially improve understanding about the role of law in adaptive management.

Fig. 2. Number of articles by publication date.




Only 11 publications (approximately 14\% of the sample) adopted interviews or surveys as a primary research method. However, some of the outcomes are worth mentioning. For example, Koontz and Bodine (2008) interviewed members of the U.S. Bureau of Land Management and the U.S. Forest Service to identify obstacles to ecosystem management implementation, and reported that adaptive management was seen as a challenging component. This overall perception was linked to the existence of legal barriers, which were identified by $17 \%$ of respondents (Koontz and Bodine 2008). Some years later, a survey of adaptive management practitioners in the USA revealed that more than $70 \%$ of the respondents felt hampered by legal and institutional constraints (Benson and Stone 2013).

Within the publications reviewed, the discussion on adaptive management and law was still highly geographically concentrated in the USA. Publications including only the USA as their geographical context accounted for approximately $64 \%$ of the literature sample. These results are consistent with the observations made by Humby (2014) on her literature review on resilience and law published in a nonpeer-reviewed journal, which also found that the USA was, by far, the most frequently studied jurisdiction. Together with the USA, countries with legal systems based on, or influenced by, the English common law system, e.g., Australia, Canada, and South Africa, were regularly used as the geographical context of publications. Although these results possibly reflect bias in our methods that exclude non-English language publications, they may also indicate a predominance of USA, and subsidiarily of other common law countries, in this academic scholarship, especially within the peer-reviewed literature. Further research in developing countries would be of particular interest because these jurisdictions may face challenges to implement adaptive management practices on account of the lack of a strong or well-defined rule of law (Garner 2016). Despite its predominance in developed countries, adaptive management approaches can be designed to serve different social-ecological and economic contexts (Schramm and Fishman 2010, nonpeerreviewed). Comparative studies would also be insightful because the conclusions from previous research conducted in a specific legal system can also be relevant to other jurisdictions (Green et al. 2015, Curran and Mascher 2016). For example, in the USA, Craig (2010a) suggested in a nonpeer-reviewed publication that state common law public trust doctrines can be used to support adaptive management in the context of climate change. New studies could investigate the feasibility of this suggestion in other common law countries, and what legal tools are available in jurisdictions adopting different legal systems.

\section{The meaning of adaptive management}

Adaptive management has no single or static meaning (Raadgever et al. 2008, Schultz and Nie 2012), which often leads to terminological confusion (McDonald and Styles 2014). Selected definitions provided by publications included in this systematic review are presented in Table 2. Adaptive management is a framework designed for managing complex and dynamic socialecological systems (Thrower 2006, Garmestani et al. 2008, Craig 2010b, Novellie et al. 2016, Ruhl 2016), in which decision making follows a structured and iterative process (Raadgever et al. 2008, Benson and Garmestani 2011, Craig and Ruhl 2014, Green et al. 2015, Fischman and Ruhl 2016, Ruhl 2016) aiming to reduce uncertainties over time (Schultz 2008, Benson and Garmestani
2011, Benson et al. 2013, Craig and Ruhl 2014, Garmestani 2014, Green et al. 2015, Fischman and Ruhl 2016, Fuentes et al. 2016) through monitoring and evaluation of management actions (Angelo 2006, Thrower 2006, Benson and Garmestani 2011, Benson and Stone 2013, Craig and Ruhl 2014, Garmestani 2014, Butler et al. 2015, Green et al. 2015, Chaffin et al. 2016, Fischman and Ruhl 2016, Wiafe 2016). The approach is intended to facilitate learning from management outcomes and, consequently, about the social-ecological systems being managed (Garmestani et al. 2008, Spies et al. 2010, Benson et al. 2013, Cosens 2013, Pratt Miles 2013, Chaffin et al. 2016, Fischman and Ruhl 2016, Fuentes et al. 2016, Wiafe 2016). Such new knowledge allows for the adjustment of previous established objectives and adopted actions (Dwyer 2011, Pratt Miles 2013, Craig and Ruhl 2014, Garmestani 2014, Green et al. 2015, Chaffin et al. 2016, Fischman and Ruhl 2016, Wiafe 2016), reaching the point where the iterative process restarts, following a cycle of continuous management improvement (Raadgever et al. 2008, Craig and Ruhl 2014, McDonald and Styles 2014, Fuentes et al. 2016).

The adaptive management process begins with a set-up phase (Craig and Ruhl 2014, Tan et al. 2015, Ruhl 2016), and the first step involves the definition of clear objectives and goals (Raadgever et al. 2008, McDonald and Styles 2014, Chaffin et al. 2016). These are defined based on available data, which are gathered to assess the current condition and the characteristics of the social-ecological system (Thrower 2006, Dwyer 2011, Holley and Sinclair 2011, Craig and Ruhl 2014, McDonald and Styles 2014). Additionally, detailed monitoring protocols must be produced, describing how the effectiveness of actions and the progress toward defined objectives and goals will be assessed (Schultz and Nie 2012, Borgström 2015, Johnson et al. 2016). Monitoring is considered essential and at the core of adaptive management (Jones 2007, Green and Garmestani 2012, Bjorkland 2013, Butler et al. 2015, Novellie et al. 2016).

The adaptive management process then moves on to its "iterative" phase, during which the defined actions are implemented, and the monitoring efforts gather new data to be evaluated (Nie and Schultz 2012, Craig and Ruhl 2014, Ruhl 2016). Learning from monitoring outcomes allows for improvement of scientific understanding of the social-ecological system (Thrower 2006). It also provides feedback about the adequacy of management objectives and implemented actions, which can be revisited and adjusted in light of new information (Jones 2007, Cosens 2013, Green et al. 2013, Garmestani 2014, Tan et al. 2015, Fuentes et al. 2016).

Adaptive management may be adopted in different forms (Biber and Eagle 2016). Although the traditional distinction between active and passive adaptive management was made by several reviewed publications (Thrower 2006, Garmestani et al. 2008, Benson and Garmestani 2011, Dwyer 2011, Holley and Sinclair 2011, Schultz and Nie 2012, Biber 2013, Craig and Ruhl 2014, Humby 2014, McDonald and Styles 2014, Fischman and Ruhl 2016), another form, which has been often mentioned by the legal scholarship, is called adaptive management lite. The concept was first mentioned by Ruhl and Fischman (2010) on a nonpeerreviewed review of adaptive management litigation in the USA, and their definition, "a watered-down version of the theory that resembles ad hoc contingency planning more than it does planned 
Table 2. Selected definitions of adaptive management extracted from the literature sample.

\begin{tabular}{|c|c|}
\hline Definition & Reference \\
\hline $\begin{array}{l}\text { "Adaptive management, a product of the nonequilibrium paradigm, is a theory of ecological oversight and administration } \\
\text { that recognizes the utility and necessity of experimentation and flexibility in identifying how complex ecosystems respond } \\
\text { to disturbances. Through its continuing evaluation of the repercussions of a preceding action, adaptive management } \\
\text { permits action and reaction in the absence of complete information. This affords the decision maker the opportunity to } \\
\text { adapt and change tactics to maximize the environmental benefits of a course of action." }\end{array}$ & Thrower (2006:873) \\
\hline $\begin{array}{l}\text { "The adaptive management model envisages an initial regulatory approval based on initially available information } \\
\text { (perhaps guess-work, estimation or 'regulatory science') followed by a period of monitoring and reporting with } \\
\text { reassessment of the appropriateness of the initial regulatory action and adjustment or amendment as required in light of } \\
\text { new information, and presumably the resolution of previously identified uncertainties." }\end{array}$ & Jones $(2007: 361)$ \\
\hline $\begin{array}{l}\text { "Although the definitions of adaptive management differ, the term generally includes four elements: (1) the articulation of } \\
\text { clear goals and measurable indicators of progress toward achieving those goals; (2) an iterative approach to making } \\
\text { decisions and the opportunity to adjust strategies; (3) the continual monitoring of outcomes and impacts; and (4) the } \\
\text { explicit acknowledgement and characterization of risks and uncertainties." }\end{array}$ & Huang et al. (2011:309) \\
\hline $\begin{array}{l}\text { "Adaptive management at its core is applied understanding about ecosystems drawn from resilience theory. This entails an } \\
\text { iterative process of decision making that integrates uncertainty and the inevitability of "surprise" (i.e., non-linear change) } \\
\text { into the management process via a learning infrastructure (Benson and Garmestani 2011). Monitoring is an essential } \\
\text { aspect of adaptive management, as information from the system (e.g., monitoring data) feeds back into the management } \\
\text { process in an iterative manner that allows managers to adapt to changing circumstances associated with managing } \\
\text { ecosystems. Thus, management actions are hypotheses to be put "at risk" in an adaptive management framework, and } \\
\text { information that allows for learning is generated to improve management decisions (Benson and Garmestani 2011)." }\end{array}$ & $\begin{array}{l}\text { Green and Garmestani } \\
(2012: 165)\end{array}$ \\
\hline $\begin{array}{l}\text { "The term 'adaptive management' has been used to describe a process of learning through monitoring ecosystem response } \\
\text { to a particular action, followed by incremental change in the action based on what is learned (Lee 1999, Folke et al. 2005, } \\
\text { Huitema et al. 2009) and generally applies to management action by a single entity." }\end{array}$ & Cosens (2013) \\
\hline $\begin{array}{l}\text { "Adaptive management is an environmental management strategy that is an iterative process of decision making and } \\
\text { attempts to reduce the inherent uncertainty in ecological systems via system monitoring (Holling 1978). Adaptive } \\
\text { management is proactive, rather than reactive, which makes it a very attractive option for sound environmental } \\
\text { management (Garmestani et al. 2008). Adaptive management uses models based upon current information to develop } \\
\text { management interventions. The system is then monitored at a rate appropriate to the system of interest, and the results } \\
\text { evaluated. From this information, models are improved and management of the system is adapted to the new information } \\
\text { in an iterative process." }\end{array}$ & Garmestani (2014:735) \\
\hline $\begin{array}{l}\text { "Adaptive management means a decisionmaking process based on the structured and iterative implementation of } \\
\text { management measures, with comprehensive monitoring of relevant system indicators, in the attempt to achieve specific } \\
\text { management goals or objectives, reduce uncertainty, or increase knowledge about the system that an agency is charged } \\
\text { with managing." }\end{array}$ & Craig and Ruhl (2014:63) \\
\hline $\begin{array}{l}\text { "Adaptive management is designed to address uncertainty, and is a structured, iterative approach to management that } \\
\text { involves hypothesis testing through management action(s), monitoring, and feedback (ie adjusting management } \\
\text { parameters)." }\end{array}$ & Green et al. (2015:334) \\
\hline $\begin{array}{l}\text { "In ideal conception, adaptive management uses an experimental approach in which actions are taken on the landscape } \\
\text { followed by monitoring to determine whether the strategy achieved desired results. Through such experimental means, } \\
\text { uncertainties can be redressed overtime, while allowing management to proceed based on the best available information." }\end{array}$ & Butler et al. (2015:565) \\
\hline $\begin{array}{l}\text { "Adaptive management is supposed to be an iterative process in which decision outcomes are continually monitored and } \\
\text { evaluated to determine whether they are achieving objectives. The feedback loops rely on goal establishment, model } \\
\text { building, performance standard setting, outcome monitoring, and recalibration. Over time, feedback and adjustments } \\
\text { provide flexibility in the face of uncertainty while simultaneously reducing uncertainty through systematic learning (Nie } \\
\text { and Schultz 2012)." }\end{array}$ & $\begin{array}{l}\text { Fischman and Ruhl } \\
\qquad(2016: 269)\end{array}$ \\
\hline $\begin{array}{l}\text { "Adaptive management involves decision making following a structured, multistep protocol designed to facilitate decision } \\
\text { making in dynamic management environments." }\end{array}$ & Ruhl (2016:418) \\
\hline $\begin{array}{l}\text { "AM [adaptive management] is the structured implementation of management actions as experiments, followed by } \\
\text { monitoring, evaluation and adjustment of management actions as needed to manage ecosystems (Allen et al. 2011, Allen } \\
\text { and Garmestani 2015)." }\end{array}$ & Chaffin et al. (2016:433) \\
\hline "Adaptive management is a framework for resource conservation that promotes iterative learning-based decision making." & Fuentes et al. (2016:209) \\
\hline $\begin{array}{l}\text { "Adaptive management is a relatively new concept that incorporates research into conservation action. Specifically, the } \\
\text { concept integrates design, management and monitoring to systematically test assumptions in order to adapt and learn. } \\
\text { Adaptive management can further be viewed as the process of hypothesizing how ecosystems management should have } \\
\text { worked with people, monitoring results, comparing them with expectations and modifying management decisions to } \\
\text { better achieve conservation objectives through improved understanding of ecological processes (Lancia et al. 1996; } \\
\text { Salafsky et al. 2001)." }\end{array}$ & Wiafe (2016:2) \\
\hline
\end{tabular}

'learning while doing"“ (Ruhl and Fischman 2010:426), was explicitly discussed by multiple publications of the literature sample (Ruhl 2011, Green and Garmestani 2012, Schultz and Nie 2012, Benson and Stone 2013, Craig and Ruhl 2014, McDonald and Styles 2014, Meretsky and Fischman 2014, Fischman and
Ruhl 2016, Novellie et al. 2016). This approach is considered "a compromised version of adaptive management" (Green and Garmestani 2012:171), in which management objectives are loosely defined, monitoring protocols are vague, and management actions triggered by monitoring thresholds are not 
clearly detailed (Nie and Schultz 2012, Craig and Ruhl 2014, Fischman and Ruhl 2016). This lack of specificities allows natural resource management agencies and other public authorities to skip essential parts of the structured and iterative learning process of adaptive management, and increase their discretion and flexibility within decision making embedded in political controversies, financial restrictions, or scientific uncertainties (Nie and Schultz 2012, Schultz and Nie 2012, Bjorkland 2013, Fischman and Ruhl 2016, Novellie et al. 2016). The rhetoric of adaptive management can be used as a smokescreen to postpone difficult decisions by leaving descriptions of responses to management actions too generic or unspecified (Green and Garmestani 2012, Craig and Ruhl 2014, Meretsky and Fischman 2014, Novellie et al. 2016). For these reasons, adaptive management lite is often seen as open-ended contingency planning, adaptive mitigation, or simply "on-the-fly" management (Schultz and Nie 2012, McDonald and Styles 2014, Meretsky and Fischman 2014, Fischman and Ruhl 2016).

\section{Legal barriers to adaptive management}

Adaptive management can face legal barriers (Benson and Garmestani 2011, Benson and Stone 2013, Craig and Ruhl 2014). Laws themselves can create difficulties for critical components of adaptive management (Koontz and Bodine 2008), and specific pieces of legislation are often mentioned as barriers to this approach. An example is the U.S. Endangered Species Act (ESA), which has been criticized for focusing on the protection of individual species, rather than the management of the overall social-ecological system (Koontz and Bodine 2008, Benson 2012), and for leaving little room for experimentation (Schultz 2008, Cosens and Williams 2012). Narrow and prescriptive rules are considered more problematic (Jantarasami et al. 2010, Green et al. 2015, Cheng et al. 2016). On the other hand, process-oriented laws are regarded to offer more opportunities for adaptation (Jantarasami et al. 2010, van Rijswick and Salet 2012, Garmestani and Benson 2013). Nevertheless, details on how the adaptive management process should occur are practically nonexistent in environmental statutes and regulations (Angelo 2006, Zellmer and Gunderson 2008, McDonald and Styles 2014).

Several aspects of law were highlighted in the literature reviewed as limiting adaptive management approaches. For example, jurisdictional boundaries, regulatory fragmentation, and legal division of landscapes among multiple owners may not match ecosystems boundaries and scales, and this context can restrain adaptation (Thrower 2006, Garmestani et al. 2008, Koontz and Bodine 2008, Craig 2010b, Jantarasami et al. 2010, Biber 2011, Cosens and Williams 2012, Cosens 2013, Preston 2013, Arnold 2014, 2015, Chaffin et al. 2014, 2016, Humby 2014, Parlee and Wiber 2014, Green et al. 2015, Curran and Masche 2016). Moreover, although stakeholder involvement and collaborative efforts are essential components for building transparency and legitimacy in adaptive management (Craig and Ruhl 2014), extensive legal requirements for public participation can burden the iterative adaptive management process by creating inefficiencies in decision making (Zellmer and Gunderson 2008, Ruhl 2012, Biber 2013, Craig and Ruhl 2014, Fischman and Ruhl 2016, Biber and Eagle 2016).

Judicial review can also make adaptive management implementation more difficult (Koontz and Bodine 2008, Schultz
2008, Craig 2010b, Biber 2011, Green and Garmestani 2012, Nie and Schultz 2012, Ruhl 2012, Schultz and Nie 2012, Craig and Ruhl 2014, Borgström 2015, Biber and Eagle 2016, Fischman and Ruhl 2016). Court decisions can provide check and balance systems, ensuring compliance with the laws produced by the legislative branch, and controlling the discretion of public authorities in charge of executing and enforcing legislation (Cosens 2013, Craig and Ruhl 2014). They also help decision making to be more reasonable and oriented to the public interest, and have the capability of increasing transparency and public participation (Craig and Ruhl 2014). However, legal systems that establish too liberal requirements for standing allow the legal challenge of a wide variety of management decisions, and can result in harmful overlitigation for adaptive management (Dwyer 2011, Craig and Ruhl 2014, McDonald and Styles 2014).

Lawsuits can be costly and time consuming, diverting the attention from improving planning, monitoring, and collaborative efforts (Koontz and Bodine 2008). Excessive opportunities for judicial review can disrupt the iterative process of adaptive management by preventing the adjustment of management actions promptly and on the basis of new knowledge generated (Craig and Ruhl 2014). Natural resource management agencies and other public authorities may be liable for the consequences of their previous decisions (Godden and Kung 2011), and this encourages a management approach more concerned with avoiding legal disputes rather than engaging in experimentation and monitoring (Craig 2010b, Bjorkland 2013). Within this context, practitioners end up being inclined to engage in adaptive management lite, rather than truly adaptive management (Craig and Ruhl 2014).

Legal mandates are another frequently reported barrier because they can be inflexible and outdated (Koontz and Bodine 2008, Godden and Kung 2011), and require specific management outcomes, e.g., narrow goals related to the recovery of specific species rather than an ecosystem approach, that discourage adaptive management practices (Benson and Stone 2013). Furthermore, the adoption of an adaptive management approach is rarely an explicit substantive requirement in legal frameworks (Schultz 2008, Benson and Garmestani 2011), and law generally does not establish clear provisions to promote learning and reduce uncertainties through the design of management actions as experiments (Craig and Ruhl 2014).

Another component of adaptive management constantly ignored by law is monitoring; many relevant statutes, such as the U.S. National Environment Policy Act (NEPA), do not mandate it (Thrower 2006, Benson and Garmestani 2011, Benson and Stone 2013, Bjorkland 2013). Although the legislation of many countries has already given attention to monitoring, for example, allowing its inclusion as a postapproval condition of licences and authorizations (Jones 2007), or even requiring responses based on monitoring outcomes (Borgström 2015), those provisions are not frequent (Benson and Garmestani 2011, Benson and Stone 2013). Legal requirements for monitoring would not necessarily lead to useful results for management or guarantee adaptive responses (Chapman 2012, McDonald and Styles 2014), but the absence of enforceable mandates can eventually increase political and budgetary constraints to monitoring (Benson and Stone 2013). 
Table 3. Law values hindering the design and implementation of adaptive management.

\begin{tabular}{|c|c|c|c|}
\hline Law value & Key Reference & Examples & \\
\hline \multirow[t]{3}{*}{ Stationarity } & Craig (2010b) & $\begin{array}{l}\text { Godden and } \\
\text { Kung (2011) }\end{array}$ & $\begin{array}{l}\text { Stationarity was identified as a feature of water management law in two Australian } \\
\text { States, Queensland and Victoria, when dealing with flood events. Both legal systems } \\
\text { adopt the 1:100-year flood risk datum as a central standard for management, assuming } \\
\text { that climate conditions are relatively stable, and that minor variations are predictable. }\end{array}$ \\
\hline & & Benson (2012) & $\begin{array}{l}\text { Stationarity was described as a concept embedded in the U.S. Endangered Species Act } \\
\text { (ESA), which focuses on restoration and recovery rather than resilience and adaptive } \\
\text { capacity. The statute takes as a premise that "extinction is not an option," assuming } \\
\text { therefore that social-ecological systems are stable. }\end{array}$ \\
\hline & & $\begin{array}{l}\text { Novellie et al. } \\
\text { (2016) }\end{array}$ & $\begin{array}{l}\text { Stationarity was noted in legislation governing the South African National Parks. They } \\
\text { argued that the National Environmental Management: Protected Areas Act (NEM: } \\
\text { PAA) establishes static goals because it requires a high level of operational detail in } \\
\text { management plans and, at the same time, subjects that any changes to plans shall be } \\
\text { approved by the highest political level authority. }\end{array}$ \\
\hline \multirow[t]{3}{*}{ Certainty } & Schultz and Nie (2012) & $\begin{array}{l}\text { Nie and Schultz } \\
\text { (2012) }\end{array}$ & $\begin{array}{l}\text { Certainty was pointed as an aspect demanded by nonfederal property owners in the } \\
\text { USA about what actions are allowed by an incidental take permit issued under the } \\
\text { ESA. }\end{array}$ \\
\hline & & Preston (2013) & $\begin{array}{l}\text { Certainty was seen as a feature of the process of imposing conditions related to land- } \\
\text { use consents. He cited mining leases as an example in Australia because they guarantee } \\
\text { access to a specific mining resource for specified periods to provide businesses with } \\
\text { certainty, and this may not take into consideration the ecological sustainability of the } \\
\text { whole ecosystem. }\end{array}$ \\
\hline & & $\begin{array}{l}\text { McDonald and } \\
\text { Styles (2014) }\end{array}$ & $\begin{array}{l}\text { Certainty was blamed for encouraging a front-end decision-making model in } \\
\text { conventional environmental impact assessment in Australia. They argue that decisions } \\
\text { about a development and what conditions should be imposed on it are made at the } \\
\text { beginning of a project, leaving few opportunities to revisit the approval at a later stage. }\end{array}$ \\
\hline \multirow[t]{3}{*}{ Finality } & Craig and Ruhl (2014) & $\begin{array}{l}\text { Cosens and } \\
\text { Williams (2012) }\end{array}$ & $\begin{array}{l}\text { Finality was stated as one aspect addressed by order-based legitimacy, one of the } \\
\text { sources of legitimacy relevant for adaptive management implementation. They } \\
\text { affirmed that order-based legitimacy also derives from the judicial review of } \\
\text { administrative actions, which provides finality through final decisions (res judicata), } \\
\text { and consideration of earlier court decisions (stare decisis). Relitigation is discouraged } \\
\text { and, consequently, the review of past management decisions is deterred. }\end{array}$ \\
\hline & & $\begin{array}{l}\text { Craig and Ruhl } \\
\text { (2014) }\end{array}$ & $\begin{array}{l}\text { Finality was acknowledged as a value of contemporary administrative law in the USA. } \\
\text { They observed that there are many requirements for front-end justification of } \\
\text { management decisions, undermining the capacity to engage in experimentation and } \\
\text { adaptation. Finality can be identified in many agency adjudications in the USA, such } \\
\text { as permitting, and even in rule making. }\end{array}$ \\
\hline & & $\begin{array}{l}\text { Borgström } \\
\text { (2015) }\end{array}$ & $\begin{array}{l}\text { Finality was considered a rooted value of administrative procedures in the context of a } \\
\text { discussion about the capacity of biodiversity conservation law in Finland to support } \\
\text { climate change adaptation. She exemplified with old water permits for hydropower } \\
\text { plants, which cannot be revised to include new conditions for mitigating impacts on } \\
\text { fisheries, as stated in a } 2006 \text { Finnish Supreme Court decision. }\end{array}$ \\
\hline
\end{tabular}

The results of this systematic review demonstrate that legal barriers to adaptive management are usually related to one or more of the following legal values: (i) stationarity; (ii) certainty; and (iii) finality. These are deeply intertwined, and empirical research has identified how they emerge in the context of adaptive management. Table 3 presents some examples of the observation of these legal values across different legal systems.

Originally coined by Milly et al. (2008), stationarity has been described as a failure of some legal frameworks to recognize the dynamics of social-ecological systems, which are constantly facing change rather than remaining stable (Thrower 2006, Craig $2010 b$, Spies et al. 2010, Benson and Garmestani 2011, Godden and Kung 2011, Huang et al. 2011, Ruhl 2011, Benson 2012, Garmestani and Benson 2013, Arnold 2014, 2015, Cosens et al. 2014, He 2014, Humby 2014, McCormack and McDonald 2014, McDonald and Styles 2014, Curran and Masche 2016, Novellie et al. 2016). Since the 1970s, many environmental laws have been influenced and shaped by the "equilibrium paradigm," a belief that, without human disturbance, ecosystems can eventually reach or maintain a natural stability (Thrower 2006, Benson and Garmestani 2011, Benson 2012, Craig and Ruhl 2014). Under this view, changes in ecological processes are considered predictable (Thrower 2006, Craig 2010b, Benson and Stone 2013, Novellie et al. 2016), occurring within a "fixed envelope of variability" (McDonald and Styles 2014:41), or a "suite of unchanging variables" (Benson 2012).

Legal frameworks tend to incorporate preservation and restoration approaches (Craig 2010b, Schramm and Fishman 2010, Spies et al. 2010, Huang et al. 2011, Benson 2012, McDonald and Styles 2014). Both approaches assume that ecosystems have a desirable and achievable "state of being," which remains historically constant (Craig 2010b). This perspective is incompatible with the adaptive capacity needed to address relevant environmental management issues, such as climate change (Craig 2010b, Spies et al. 2010, Huang et al. 2011, Ruhl 2011, McCormack and McDonald 2014). By not acknowledging 
the complexity and unpredictability of social-ecological systems, legal frameworks based on stationarity can be too rigid for adaptive management (Craig 2010b, Benson and Garmestani 2011, Godden and Kung 2011, McCormack and McDonald 2014, Novellie et al. 2016).

One of the reasons that law has easily embraced stationarity derives from the aim of legal systems to provide certainty to social relations (Thrower 2006, Koontz and Bodine 2008, Ruhl and Fischman 2010, Green and Garmestani 2012, Nie and Schultz 2012, Schreiber 2012, Schultz and Nie 2012, van Rijswick and Salet 2012, Benson and Stone 2013, Bjorkland 2013, Demange 2013, Green et al. 2013, Preston 2013, Arnold 2014, 2015, Garmestani 2014, Humby 2014, McDonald and Styles 2014, West and Schultz 2015, Camacho and Glicksman 2016, Curran and Masche 2016). Law is essential to ensure the organization of the various societal interactions (Schreiber 2012). Ruhl (2012) highlighted that law's overall purpose "is to produce more order than chaos," thus it is concerned with the creation and maintenance of the social stability for the operation of human activities. For example, the idea that the same rules will be equally applied to all favors economic pursuits (Cosens and Williams 2012). The usual goal of legal frameworks is to always determine an accurate connection between causes and effects, or at least provide a sensation of certainty, and this approach may conflict with the adaptive management imperative of acknowledging the uncertainties of the social-ecological systems (Koontz and Bodine 2008, Green et al. 2015). Moreover, the need for legal certainty may reduce the flexibility required to allow for adaptation in light of new information (Green et al. 2013, Garmestani 2014).

The search for certainty is commonly materialized in law by means of a front-end approach to management, in which decisions are made at the very beginning of the processes, relying on the ability to predict all the environmental and social consequences that an action can generate (Thrower 2006, Jones 2007, Craig 2010b, Benson and Garmestani 2011, Green and Garmestani 2012, Nie and Schultz 2012, Ruhl 2012, Schultz and Nie 2012, Benson and Stone 2013, Craig and Ruhl 2014, McDonald and Styles 2014, Green et al. 2015, Fischman and Ruhl 2016). This front-end style of decision making has become part of the legal foundations of natural resource management, and has been well received not only by the courts and those responsible for the design and implementation of policies, laws, and regulations (Ruhl 2012), but also by environmental and stakeholder groups (Thrower 2006).

Front-end management fosters another law value that is considered by Craig and Ruhl (2014) as the most in tension with adaptive management: finality. Finality implies that legal systems generally create an environment in which management decisions should not only be made upfront, but also seek a final determination (Thrower 2006, Benson and Garmestani 2011, Cosens and Williams 2012, Benson and Stone 2013, Cosens 2013, Garmestani and Benson 2013, Craig and Ruhl 2014, Cosens et al. 2014, Borgström 2015, Green et al. 2015, Fischman and Ruhl 2016). Craig and Ruhl (2014:34) define finality as "the insistence on final resolutions by administrative agencies that will be definitively upheld or rejected by the courts" within the context of the U.S. Administrative Law. They argued that law stimulates agencies to focus on the upfront justification for their actions that can be subjected to judicial review, and to avoid the reopening of decisions already made, once they are judicially confirmed (Craig and Ruhl 2014).

Finality is essentially a result of a conflict between science and law because the former has in its nature the constant desire to revisit answered questions and constructions of truth, and the latter is more concerned with a scenario of economic stability, which involves decisions capable of putting an end to conflicts (Cosens and Williams 2012, Cosens 2013). As a consequence, this law value may hamper the iterative and structured process adopted by adaptive management, because it is framed for linear decision-making approaches (Benson and Garmestani 2011). Finality discourages experimentation (Craig and Ruhl 2014), and prevents the level of flexibility required to adapt in the face of change or new information (Thrower 2006, Cosens 2013, Craig and Ruhl 2014, Green et al. 2015).

\section{Overcoming the legal barriers to adaptive management}

Despite the legal barriers and law values described above, adaptive management has been used, or at least attempted, within many existing legal frameworks not intentionally designed for its adoption (Jones 2007, Schultz 2008). The approach is not necessarily incompatible with current legislation (Schultz 2008, Stuart-Hill and Schulze 2010, Borgström 2015) because many legal mandates have a level of vagueness that allows adaptive management to be an option (Spies et al. 2010, Benson and Garmestani 2011). However, with a "regulatory home," adaptive management implementation can certainly be less problematic (Benson and Garmestani 2011).

In the USA, Fischman and Ruhl (2016) highlighted that agencies and courts would benefit from legislative standards for adaptive management, which are rare in U.S. federal statutes. Similar conclusions were reached by Kwasniak (2010) in Canada, where the Canadian Environmental Assessment Act (CEAA) does not provide a detailed procedure on how to implement adaptive management, and only expressly authorizes the approach in relation to follow-up programs under environmental assessment processes, leaving out other relevant phases, such as project planning and design. Kwasniak (2010) argued that the lack of specifics in the CEAA may have contributed to a Canadian court's misinterpretation of adaptive management principles in the Penimba Institute for Appropriate Development et al. v Attorney General of Canada and Imperial Oil Resources Ventures Limited (the "Kearl Mines case"). This case was related to a proposed oil sands mine and, according to Kwasniak (2010), the court's interpretation of CEAA (i) authorized the use of adaptive management to deal with uncertain adverse environmental effects that may prove to be significant and, therefore, (ii) allowed for the adoption of mitigation measures involving uncertainty about their efficacy for dealing with significant adverse environmental effects, and (iii) considered adaptive management as an offset to the precautionary principle, based on statements made on the decision. She then suggested amendments in this statute to clarify the role of the approach in the Canadian environmental assessment process (Kwasniak 2010).

These scholars are not alone as many have been arguing that some kind of reform may be required to improve law so that it is better prepared to deal with the uncertainty of social-ecological systems and manage for resilience (Craig 2010b, Spies et al. 2010, Benson and Garmestani 2011, Benson 2012, Green and Garmestani 2012, 
Ruhl 2012, Benson and Stone 2013, Cosens 2013, Garmestani and Benson 2013, Preston 2013, Chaffin et al. 2014, Craig and Ruhl 2014, He 2014, Garmestani 2014, McDonald and Styles 2014, Green et al. 2015, Borgström 2015, Novellie et al. 2016). Accommodating adaptive management into legal systems can be difficult (Ruhl 2012). By moving toward adaptive management, law will inevitably enter into an uncomfortable environment embedded with nonlinear changes and unpredictability (Craig $2010 b$ ). The challenge of legal reform must, therefore, be faced with optimism, just like many adaptive management practitioners interviewed by Benson and Stone (2013) have demonstrated. From those who agreed with the existence of legal constraints to adaptive management, $53 \%$ were positive about eliminating them through changes in law (Benson and Stone 2013).

Within the literature reviewed, increasing the flexibility of legal frameworks was seen as an imperative for responding to the legal barriers of adaptive management (Thrower 2006, Craig 2010b, Benson and Garmestani 2011, Herrfahrdt-Pähle and Pahl-Wostl 2012, Benson and Stone 2013, Garmestani and Benson 2013, Green et al. 2013, Preston 2013, Craig and Ruhl 2014, Garmestani 2014, He 2014, McDonald and Styles 2014, Borgström 2015, Fischman and Ruhl 2016, Frost et al. 2016, Fuentes et al. 2016, Garner 2016, Jaeckel 2016, Novellie et al. 2016). Innovative ways will have to be pursued to balance the flexibility needed for adaptive management and the stability demanded by law (Thrower 2006, Angelo 2008, van Rijswick and Salet 2012, Garmestani 2014, Pidot 2015, Cosens and Chaffin 2016, Fischman and Ruhl 2016). Flexible legal frameworks designed to accommodate adaptive management will have to limit the discretion of actors who may be inclined to remain in inertia or deviate from regulatory and management objectives (Craig 2010b, Bjorkland 2013). The task to improve legal flexibility for adaptive management, therefore, must be conducted carefully and responsibly because it can leave room for political and economical interferences that may ultimately compromise the original intention of those who put it into consideration in the first place (Biber and Eagle 2016).

Suggestions related to legal reform have included binding commitments to implement adaptive management under certain circumstances, in order to increase enforceability and legitimacy of the approach (Benson and Garmestani 2011, Nie and Schultz 2012, Bjorkland 2013), and clear provisions related to the implementation phase, by defining parameters to be followed during the various phases of the adaptive management cycle. Establishing such requirements would contribute to reducing litigation (Thrower 2006) because courts would have a legal basis to evaluate and support adaptive management initiatives (Craig and Ruhl 2014).

Possible ways to make broad processes established by legal frameworks more flexible and adaptable can include "in-built review mechanisms or sunset clauses for regulatory objectives or entire statutes, enhanced public participation processes, better mechanisms for dealing with private property rights, and multilayered and multi-jurisdiction governance arrangements" (McDonald and Styles 2014:40). Furthermore, management objectives can be established with more attention to resilience and adaptive capacity, allowing for flexibility rather than embracing goals based on the stationarity approach (McDonald and Styles
2014). For example, instead of pursuing specific and static volumes or flow regimes, water management law in Australia has shifted its focus to protecting "key ecosystem functions" and "key environmental outcomes" (McDonald and Styles 2014). However, allowing for this flexibility also involves limiting the discretion of those adopting an adaptive management approach, by ensuring that management objectives are not too broad and open-ended that would not enable the measurement of performance (Craig and Ruhl 2014, McDonald and Styles 2014). Legal frameworks must then have and require the definition of goals that are not only flexible, but also clear, specific, and measurable, in order to avoid adaptive management lite practices (Craig and Ruhl 2014, McDonald and Styles 2014).

Legal reform can create or refine monitoring and evaluation requirements (Thrower 2006, Craig 2010b, Schramm and Fishman 2010, Benson and Garmestani 2011, Holley and Sinclair 2011, Benson and Stone 2013, Preston 2013, Craig and Ruhl 2014, McDonald and Styles 2014, Borgström 2015, McDonald et al. 2016). Legal mechanisms can also be designed to increase funding for monitoring (Craig 2010b, Benson and Stone 2013), while an enforceable monitoring mandate would have the potential of stimulating the allocation of financial resources for adaptive management implementation (Benson and Garmestani 2011). Particular attention must be given to establishing adequate time frames in legislation for evaluating, sharing, and reporting the information gathered through monitoring (Schramm and Fishman 2010, Cosens 2013, Craig and Ruhl 2014, McDonald and Styles 2014, Borgström 2015).

Legal tools can be applied to improve the capacity to respond to changes based on the knowledge gained (McDonald and Styles 2014, Borgström 2015). A legal framework designed for adaptive management must provide feedback-loop processes, with opportunities for evaluation and adjustments of management actions in light of new monitoring data. In this sense, laws and regulations can offer staged and tiered processes (McDonald and Styles 2014, Meretsky and Fischman 2014), and design conditional approvals that allow for future modifications or management interventions once predefined triggers/thresholds are reached or verified (Nie and Schultz 2012, Schultz and Nie 2012, McDonald and Styles 2014). Proportionate resource allocation models and decisions rules, such as fishing quotas for harvest control and water entitlements based on resource availability, are another way to provide a regulatory incentive for adaptive management (McDonald and Styles 2014).

Most of the suggestions described above have already been adopted in different jurisdictions, yet the ability to implement adaptive management has not always increased. Flexibility can exist on paper without positive repercussions on practice (Benson and Stone 2013). The fact is that the adaptive management literature still does not provide many specifics concerning the legal framework (Raadgever et al. 2008). As our results show, this does not mean that the level of understanding of the legal constraints related to adaptive management implementation has not grown over the last years, nor that solutions for these shortcomings have not been proposed. Nevertheless, new studies with a focus on thinking about how we can use these recommendations in the real world to improve the law would add valuable contributions. More empirical research is needed on how to assess the capacity of 
specific legal frameworks to enable adaptive management, and to make tailor-made and feasible legal reform proposals for particular contexts.

In the USA, the first effort in this direction was made by Craig and Ruhl (2014). They drafted a detailed legislation model, which creates an "adaptive management track" for specific situations as an alternative to the conventional decision-making process of $U$. S. Administrative Law. Their "Model Adaptive Management Procedure Act" aims essentially to overcome the front-end style of decision making, by preserving finality, public participation, judicial review, and increasing the flexibility of agencies for adaptive management implementation. They proposed a different approach to finality, which would be understood not in view of the administrative process itself, "but rather by the goals that the adaptive management project is trying to achieve" (Craig and Ruhl 2014:42). Instead of a heavy focus on upfront public participation, they suggested multiple (but punctuated) moments for the involvement of the relevant stakeholders as the proposed project or plan evolves over time, combined with reporting requirements at regular intervals. Not every adjustment would trigger the requirements of public notice and comment, because this would undermine the capacity to timely implement the lessons learned. The same logic would be applied to the availability of judicial review.

In a nonpeer-reviewed publication, Biber (2014) engaged in dialogue with Craig and Ruhl (2014), suggesting amendments to their statutory model with the main purpose of improving the balance between the flexibility needed for adaptive management and the level of discretion agencies would have by choosing the "adaptive management track." For instance, he proposed a review of adaptive management plans at least every six years, in which the agency would have to demonstrate why adaptive management is still required, and how the plan will continue to be effective. This suggestion aims to avoid agencies continuing on the "adaptive management track" ad eternum just to skip judicial review and public participation requirements. However, Biber (2014) acknowledged that Craig and Ruhl's pioneer contribution has many merits, and we believe that their dialogue has the potential to offer relevant insights to other legal systems beyond the context of the U.S. Administrative Law.

The success of any attempt of legal reform to accommodate adaptive management within a specific legal framework will be strongly influenced by the governance structure in place. The term "governance" encompasses the laws, regulations, and other legal instruments, and therefore the legal framework to be reformed, but also comprises informal institutions, such as practices, customs, social norms, power relationships, and the organizations involved in governing the management of a social-ecological system (Cosens and Williams 2012, Cosens 2013, Chaffin et al. 2014, Cosens et al. 2014). Proposals to change the law will necessarily involve a process of resolving trade-offs within a complex social environment of different stakeholders and interests.

For this reason, adaptive management as theorized is more suitable for projects that have a single organization responsible for clear and distinct goals, being only part of the solution for the management of complex systems involving multiple goals that may conflict, multiple scales, and multiple authorities with overlapping jurisdiction (Cosens 2013, Green et al. 2015). A new body of literature has recently started to identify shortcomings in adaptive management related to governance issues and legal barriers to more adaptive forms of governance (Cosens et al. 2014). In this sense, adaptive governance has been suggested for coupling law and social-ecological resilience (Green et al. 2015). That is, for law to better facilitate adaptive management, there must be a governance structure in place that acknowledges the uncertainty and complexity of social-ecological systems (Chaffin et al. 2014), and recognizes the linkages between the social and ecological subsystems (Green et al. 2013).

In a comprehensive review, Chaffin et al. (2014) defined adaptive governance as "a range of interactions between actors, networks, organizations, and institutions emerging in pursuit of a desired state for social-ecological systems." The approach has been perceived "as the institutional and societal structures that facilitate adaptive management" (Cosens et al. 2014:2345), and the type of governance that provides the level of flexibility needed for adaptive management (Cosens and Williams 2012). Adaptive governance has broader boundaries, including not only its critical adaptive management component (Chaffin et al. 2014) but also integration, collaboration, and cooperation across the formal and informal institutions, levels of government, and relevant stakeholders (Cosens 2013, Chaffin et al. 2014, Green et al. 2015, West and Schultz 2015). It also involves meaningful public participation in proper moments of decision-making processes (Green et al. 2015, van Buuren et al. 2015, Novellie et al. 2016).

The emergence of adaptive governance is a result of the shortcomings of centralized, top-down and command-control approaches to governance, which have shown failures in dealing with the complexity of social-ecological systems (Chaffin et al. 2014). Adaptive governance advocates for increasing cross-scales interactions and social networks among stakeholders within the governance system, and encourages a focus on matching the scale of governance to the scale of the ecosystem, which was defined by Huitema et al. (2009) as managing at the "bioregional scale" (Cosens and Williams 2012, Cosens 2013, Chaffin et al. 2014, Cosens et al. 2014). In order to implement this approach, adaptive governance calls for polycentricity, i.e., multiple governance units of power at multiple scales, with partially redundant and overlapping authority to act (Cosens and Williams 2012, Cosens 2013, Garmestani and Benson 2013, Chaffin et al. 2014, Cosens et al. 2014, van Buuren et al. 2015, West and Schultz 2015, Cosens and Chaffin 2016, Novellie et al. 2016). Polycentric governance enables decision making to be closer to the social or environmental issue demanding an action, through increasing the capacity for management at the local scale, while retaining a network with the higher scales of the governance system (Cosens and Williams 2012). Although law plays a critical role in supporting those components, it is often an aspect ignored by the adaptive governance scholarship (Green et al. 2015).

\section{CONCLUSION}

More than 20 years ago, Iles (1996) warned that more studies on ways to overcome legal barriers to adaptive management were necessary. Our systematic review contributes to ongoing efforts toward the design of legal frameworks that are better fitted to deal with the complexity and uncertainties of social-ecological systems. Research in the USA and other countries with legal 
systems based on common law has evolved significantly over recent years, and we also encourage other scholars to accept and join this challenge, particularly those from legal jurisdictions where the discussion on adaptive management and law is not so advanced.

A convergent discourse is that accommodating adaptive management into legal frameworks will likely require some kind of reform of existing laws, regulations, and other legal instruments. Dialogues on specific legislative proposals have begun to emerge in this direction (Biber 2014, Craig and Ruhl 2014, Craig et al. 2017a). Our results show that the peer-reviewed English language literature has evolved to describe several legal barriers to adaptive management, and has also provided suggestions on how to address these obstacles. Adaptive governance has been identified as a way to facilitate adaptive management implementation (Cosens et al. 2014), and the function law plays within this approach has just recently turned into a topic of interest (Green et al. 2015).

The design of legal institutions balancing the flexibility required for adaptive management and the stability demanded by law needs to be more deeply explored to ensure the successful practice of this approach. However, reviews indicate that legal flexibility cannot be a synonym for freedom to act (Biber and Eagle 2016). Investigations on how flexible legal strategies can be designed and implemented will have to consider responsible ways of conferring discretion for those implementing adaptive management approaches.

Although the assessed scholarship has helped to build an overall understanding of the relationship between adaptive management and law, and on how adaptive governance can support this coupling, the specificities of legal systems vary significantly across countries and their different levels of government. Our conclusions cannot be generalized to all jurisdictions. Further research is needed to test these ideas in different legal contexts and social-ecological systems. New studies using other sources, such as non-English publications and a detailed analysis of nonpeer-reviewed scholarship will probably offer additional observations to the research questions we pose in this systematic review.

Future contributions could expand this body of research to unexplored legal systems and specific environmental management approaches facing problems with their adaptive management component, such as ICM. Comparative studies have the potential to stimulate learning from past and ongoing experiences of applying different legal frameworks in different jurisdictions. In particular, empirical research built on interviews with stakeholders who are involved with the governance and management of social-ecological systems may provide valuable lessons of how law has been affecting positively or negatively the capacity to implement adaptive management policies and strategies.

Responses to this article can be read online at: http://www.ecologyandsociety.org/issues/responses. php/10060

\section{Acknowledgments:}

This research is supported by an Australian Government Research Training Program (RTP) Scholarship.

\section{LITERATURE CITED}

Allen, C. R., J. J. Fontaine, K. L. Pope, and A. S. Garmestani. 2011. Adaptive management for a turbulent future. Journal of Environmental Management 92(5):1339-1345. http://dx.doi. org/10.1016/j.jenvman.2010.11.019

Angelo, M. J. 2006. Embracing uncertainty, complexity and change: an eco-pragmatic reinvention of a first-generation environmental law. Ecology Law Quarterly 33(1):105-202. http:// dx.doi.org/10.2139/ssrn.788504

Angelo, M. J. 2008. Stumbling toward success: a story of adaptive law and ecological resilience. Nebraska Law Review 87 (4):950-1007. [online] URL: https://digitalcommons.unl.edu/nlr/ vol $87 /$ iss $4 / 3 /$

Arnold, C. A. 2014. Adaptive water law. University of Kansas Law Review 62(4):1043-1090. [online] URL: https://law.ku.edu/sites/ law.drupal.ku.edu/files/docs/law_review/v62/6\%20KLR $\% 20$ Site $\%$ 20Arnold Final $\% 20$ Press.pdf

Arnold, C. A. 2015. Environmental law, episode IV: a new hope? Can environmental law adapt for resilient communities and ecosystems? Journal of Environmental and Sustainability Law 21 (1):1-45. [online] URL: https://scholarship.law.missouri.edu/jes1/ vol21/iss $1 / 3$

Babbie, E. 2007. The practice of social research. 11th edition. Thomson Wadsworth, Belmont, California, USA.

Ballantyne, M., and C. M. Pickering. 2015. The impacts of trail infrastructure on vegetation and soils: current literature and future directions. Journal of Environmental Management 164:53-64. http://dx.doi.org/10.1016/j.jenvman.2015.08.032

Benson, M. H. 2012. Intelligent tinkering: the Endangered Species Act and resilience. Ecology and Society 17(4):28. http://dx.doi. org/10.5751/ES-05116-170428

Benson, M. H., and A. S. Garmestani. 2011. Embracing panarchy, building resilience and integrating adaptive management through a rebirth of the National Environmental Policy Act. Journal of Environmental Management 92(5):1420-1427. http://dx.doi. org/10.1016/j.jenvman.2010.10.011

Benson, M. H., R. R. Morrison, and M. C. Stone. 2013. A classification framework for running adaptive management rapids. Ecology and Society 18(3):30. http://dx.doi.org/10.5751/ ES-05707-180330

Benson, M. H., and C. Schultz. 2015. Adaptive management and law. Pages 39-59 in C. R. Allen, and A. S. Garmestani, editors. Adaptive management of social-ecological systems. Springer, Dordrecht, Netherlands. http://dx.doi.org/10.1007/978-94-017-9682-8_4

Benson, M. H., and A. B. Stone. 2013. Practitioner perceptions of adaptive management implementation in the United States. Ecology and Society 18(3):32. http://dx.doi.org/10.5751/ ES-05613-180332 
Biber, E. 2011. The problem of environmental monitoring. University of Colorado Law Review 83(1):1-82. [online] URL: http://lawreview.colorado.edu/wp-content/uploads/2013/11/8.-BiberFINAL_s.pdf

Biber, E. 2013. Adaptive management and the future of environmental law. Akron Law Review 46(4):5. [online] URL: http://ideaexchange.uakron.edu/akronlawreview/vol46/iss4/5

Biber, E. 2014. Craig and Ruhl's model adaptive management procedures act: proposed amendments. Idaho Law Review 51 (1):257-278. [online] URL: http://www.uidaho.edu/-/media/ UIdaho-Responsive/Files/law/law-review/articles/volume-51/51-1biber-eric.ashx?la=en \&hash=6B015951FFC3E6D3C5F224C09F830EA812075F63

Biber, E., and J. Eagle. 2016. When does legal flexibility work in environmental law? Ecology Law Quarterly 42(4):787-840. http:// dx.doi.org/10.15779/Z38RZ9Z

Birgé, H. E., C. R. Allen, A. S. Garmestani, and K. L. Pope. 2016. Adaptive management for ecosystem services. Journal of Environmental Management 183(2):343-352. http://dx.doi. org/10.1016/j.jenvman.2016.07.054

Bjorkland, R. 2013. Monitoring: the missing piece. A critique of NEPA monitoring. Environmental Impact Assessment Review 43:129-134. http://dx.doi.org/10.1016/j.eiar.2013.07.001

Borgström, S. 2015. Assessing the capacity of nature conservation law to help biodiversity adapt to climate change: the case of Finland. Review of European, Comparative and International Environmental Law 24(1):69-82. http://dx.doi.org/10.1111/ reel.12094

Butler, W. H., A. Monroe, and S. Mc Caffrey. 2015. Collaborative implementation for ecological restoration on U.S. public lands: implications for legal context, accountability, and adaptive management. Environmental Management 55(3):564-577. http:// dx.doi.org/10.1007/s00267-014-0430-8

Camacho, A. E., and R. L. Glicksman. 2016. Legal adaptive capacity: how program goals and processes shape federal land adaptation to climate change. University of Colorado Law Review 87(3):711-826. [online] URL: http://lawreview.colorado.edu/wpcontent/uploads/2016/01/8.-87.3-Camacho-Glicksman_Final-Revised. pdf

Carter, R. W., S. Thok, V. O'Rourke, and T. Pearce. 2015. Sustainable tourism and its use as a development strategy in Cambodia: a systematic literature review. Journal of Sustainable Tourism 23(5):797-818. http://dx.doi.org/10.1080/09669582.2014.978787

Chaffin, B. C., H. Gosnell, and B. A. Cosens. 2014. A decade of adaptive governance scholarship: synthesis and future directions. Ecology and Society 19(3):56. http://dx.doi.org/10.5751/ ES-06824-190356

Chaffin, B. C., W. D. Shuster, A. S. Garmestani, B. Furio, S. L. Albro, M. Gardiner, M. Spring, and O. O. Green. 2016. A tale of two rain gardens: barriers and bridges to adaptive management of urban stormwater in Cleveland, Ohio. Journal of Environmental Management 183(2):431-441. http://dx.doi. org/10.1016/j.jenvman.2016.06.025
Chapman, P. M. 2012. Adaptive monitoring based on ecosystem services. Science of the Total Environment 415:56-60. http://dx. doi.org/10.1016/j.scitotenv.2011.03.036

Cheng, A. S., R. J. Gutiérrez, S. Cashen, D. R. Becker, J. Gunn, A. Merrill, D. Ganz, M. Liquori, D. S. Saah, and W. Price. 2016. Is there a place for legislating place-based collaborative forestry proposals?: Examining the Herger-Feinstein Quincy Library Group Forest Recovery Act Pilot Project. Journal of Forestry 114 (4):494-504. http://dx.doi.org/10.5849/jof.15-074

Cosens, B. A. 2013. Legitimacy, adaptation, and resilience in ecosystem management. Ecology and Society 18(1):3. http://dx. doi.org/10.5751/ES-05093-180103

Cosens, B. A., and B. C. Chaffin. 2016. Adaptive governance of water resources shared with indigenous peoples: the role of law. Water 8(3):97. http://dx.doi.org/10.3390/w8030097

Cosens, B. A., R. K. Craig, S. Hirsch, C. A. (T.) Arnold, M. H. Benson, D. A. DeCaro, A. S. Garmestani, H. Gosnell, J. Ruhl, and E. Schlager. 2017. The role of law in adaptive governance. Ecology and Society 22(1):30. http://dx.doi.org/10.5751/ ES-08731-220130 http://dx.doi.org/10.5751/ES-08731-220130

Cosens, B. A., L. H. Gunderson, C. R. Allen, and M. H. Benson. 2014. Identifying legal, ecological and governance obstacles, and opportunities for adapting to climate change. Sustainability 6 (4):2338-2356. http://dx.doi.org/10.3390/su6042338

Cosens, B. A., and M. K. Williams. 2012. Resilience and water governance: adaptive governance in the Columbia River Basin. Ecology and Society 17(4):3. http://dx.doi.org/10.5751/ES-04986-170403

Craig, R. K. 2010a. Adapting to climate change: the potential role of state common-law public trust doctrines. Vermont Law Review 34(4):781-854. [online] URL: http://vtlawreview. wpengine.com/wp-content/uploads/2012/02/craig.pdf

Craig, R. K. 2010b. "Stationarity is dead" - long live transformation: five principles for climate change adaptation law. Harvard Environmental Law Review 34(1):9-73. [online] URL: http://www.law.harvard.edu/students/orgs/elr/vol34 1/9-74.pdf

Craig, R. K., A. S. Garmestani, C. R. Allen, C. A. Arnold, H. E. Birgé, D. A. DeCaro, A. K. Fremier, H. Gosnell, and E. Schlager. 2017b. Balancing stability and flexibility in adaptive governance: an analysis of tools available in U.S. environmental law. Ecology and Society 22(2):3. http://dx.doi.org/10.5751/ES-08983-220203

Craig, R. K., and J. B. Ruhl. 2010. Governing for sustainable coasts: complexity, climate change, and coastal ecosystem protection. Sustainability 2(5):1361-1388. http://dx.doi.org/10.3390/ $\underline{\text { su2051361 }}$

Craig, R. K., and J. B. Ruhl. 2014. Designing administrative law for adaptive management. Vanderbilt Law Review 67(1):1-88. http://dx.doi.org/10.2139/ssrn.2222009

Craig, R. K., J. B. Ruhl, E. D. Brown, and B. K. Williams. $2017 a$. A proposal for amending administrative law to facilitate adaptive management. Environmental Research Letters 12(7):1-17. http:// dx.doi.org/10.1088/1748-9326/aa7037

Curran, D., and S. Mascher. 2016. Adaptive management in water law: evaluating Australian (New South Wales) and Canadian 
(British Columbia) law reform initiatives. McGill Journal of Sustainable Development Law 12(2):177-227. http://dx.doi. org/10.2139/ssrn.3007790

DeCaro, D. A., C. A. (T.) Arnold, E. F. Boamah, and A. S. Garmestani. 2017a. Understanding and applying principles of social cognition and decision making in adaptive environmental governance. Ecology and Society 22(1):33. http://dx.doi. org/10.5751/ES-09154-220133

DeCaro, D. A., B. C. Chaffin, E. Schlager, A. S. Garmestani, and J. B. Ruhl. 2017b. Legal and institutional foundations of adaptive environmental governance. Ecology and Society 22(1):32. http:// dx.doi.org/10.5751/ES-09036-220132

Demange, L. H. L. 2013. The principle of resilience. Pace Environmental Law Review 30(2):695-810. [online] URL: https:// digitalcommons.pace.edu/pelr/vol30/iss2/11/

Doremus, H. 2001. Adaptive management, the Endangered Species Act, and the institutional challenges of "New Age" environmental protection. Washburn Law Journal 41(1):50-89. [online] URL: http://contentdm.washburnlaw.edu/cdm/ref/collection/ wlj/id/5232

Drisko, J., and T. Maschi. 2015. Content analysis. Oxford University Press, New York, New York, USA. http://dx.doi. org/10.1093/acprof:oso/9780190215491.001.0001

Dwyer, G. 2011. Standing, adaptive management and the Queensland Lungfish: Wide Bay Conservation Council Inc v Burnett Water Pty Ltd. Macquarie Journal of International and Comparative Environmental Law 7(1):81-93. [online] URL: http:// www.austlii.edu.au/au/journals/MqJIICEnvLaw/2011/4.pdf

Falagas, M. E., E. I. Pitsouni, G. A. Malietzis, and G. Pappas. 2008. Comparison of PubMed, Scopus, Web of Science, and Google Scholar: strengths and weaknesses. Federation of American Societies for Experimental Biology (FASEB) Journal 22:338-342. http://dx.doi.org/10.1096/fj.07-9492LSF http://dx. doi.org/10.1096/fj.07-9492LSF

Fischman, R. L., and J. B. Ruhl. 2016. Judging adaptive management practices of U.S. agencies. Conservation Biology 30 (2):268-275. http://dx.doi.org/10.1111/cobi.12616

Frost, M., G. Bayliss-Brown, P. Buckley, M. Cox, S. R. Dye, W. G Sanderson, B. Stoker, and N. W. Harvey. 2016. A review of climate change and the implementation of marine biodiversity legislation in the United Kingdom. Aquatic Conservation: Marine and Freshwater Ecosystems 26(3):576-595. http://dx.doi. org/10.1002/aqc. 2628

Fuentes, M. M. P. B., L. Chambers, A. Chin, P. Dann, K. Dobbs, H. Marsh, E. S. Poloczanska, K. Maison, M. Turner, and R. L. Pressey. 2016. Adaptive management of marine mega-fauna in a changing climate. Mitigation and Adaptation Strategies for Global Change 21(2):209-224. http://dx.doi.org/10.1007/s11027-014-9590-3

Gallacher, J., N. Simmonds, H. Fellowes, N. Brown, N. Gill, W. Clark, C. Biggs, and L. D. Rodwell. 2016. Evaluating the success of a marine protected area: a systematic review approach. Journal of Environmental Management 183(1):280-293. http://dx.doi. org/10.1016/j.jenvman.2016.08.029
Garmestani, A. S. 2014. Sustainability science: accounting for nonlinear dynamics in policy and social-ecological systems. Clean Technologies and Environmental Policy 16(4):731-738. http://dx. doi.org/10.1007/s10098-013-0682-7

Garmestani, A. S., and C. R. Allen, editors. 2014. Socialecological resilience and law. Columbia University Press, New York, New York, USA. http://dx.doi.org/10.7312/garm16058

Garmestani, A. S., and C. R. Allen. 2015. Adaptive management of social-ecological systems: the path forward. Pages 255-262 in C. R. Allen, and A. S. Garmestani, editors. Adaptive management of social-ecological systems. Springer, Dordrecht, Netherlands. http://dx.doi.org/10.1007/978-94-017-9682-8 14

Garmestani, A. S., C. R. Allen, and H. Cabezas. 2008. Panarchy, adaptive management and governance: policy options for building resilience. Nebraska Law Review 87(4):1036-1054. [online] URL: https://digitalcommons.unl.edu/nlr/vol87/iss4/5/

Garmestani, A. S., and M. H. Benson. 2013. A framework for resilience-based governance of social-ecological systems. Ecology and Society 18(1):9. http://dx.doi.org/10.5751/ES-05180-180109

Garner, E. L. 2016. Adapting water laws to increasing demand and a changing climate. Water International 41(6):883-899. http:// dx.doi.org/10.1080/02508060.2016.1214775

Gee, D. 2013. A survey of major law libraries around the world. International Journal of Legal Information 41(2):108-161. [online] URL: https://ssrn.com/abstract=2316735

Gibbs, G. R. 2007. Analyzing qualitative data. Sage, Thousand Oaks, California, USA. http://dx.doi.org/10.4135/9781849208574

Godden, L., and A. Kung. 2011. Water law and planning frameworks under climate change variability: systemic and adaptive management of flood risk. Water Resources Management 25(15):4051-4068. http://dx.doi.org/10.1007/s11269-011-9887$\underline{\mathrm{x}}$

Green, O. O., B. A. Cosens, and A. S. Garmestani. 2013. Resilience in transboundary water governance: the Okavango River Basin. Ecology and Society 18(2):23. http://dx.doi.org/10.5751/ ES-05453-180223

Green, O. O., and A. S. Garmestani. 2012. Adaptive management to protect biodiversity: best available science and the Endangered Species Act. Diversity 4(2):164-178. http://dx.doi.org/10.3390/ $\underline{\mathrm{d} 4020164}$

Green, O. O., A. S. Garmestani, C. R. Allen, L. H Gunderson, J. B. Ruhl, C. A. Arnold, N. A. J. Graham, B. A. Cosens, D. G Angeler, B. C. Chaffin, and C. S. Holling. 2015. Barriers and bridges to the integration of social-ecological resilience and law. Frontiers in Ecology and the Environment 13(6):332-337. http://dx. doi.org/10.1890/140294

Gupta, J., C. Termeer, J. Klostermann, S. Meijerink, M. Van den Brink, P. Jong, S. Nooteboom, and E. Bergsma. 2010. The adaptive capacity wheel: a method to assess the inherent characteristics of institutions to enable the adaptive capacity of society. Environmental Science and Policy 13(6):459-471. http:// dx.doi.org/10.1016/j.envsci.2010.05.006

He, X. 2014. Setting the legal enabling environment for adaptation mainstreaming in environmental management in China: applying 
key environmental law principles. Asia Pacific Journal of Environmental Law 17:23-63. http://dx.doi.org/10.2139/ssrn.2521352

Herrfahrdt-Pähle, E., and C. Pahl-Wostl. 2012. Continuity and change in social-ecological systems: the role of institutional resilience. Ecology and Society 17(2):8. http://dx.doi.org/10.5751/ ES-04565-170208

Holley, C., and D. Sinclair. 2011. Collaborative governance and adaptive management: (mis)applications to groundwater, salinity and run-off. Australasian Journal of Natural Resources Law and Policy 14(1):37-69.

Holling, C. S. 1978. Adaptive environmental assessment and management. Wiley, Chichester, UK.

Holling, C. S., and S. M. Sundstrom. 2015. Adaptive management, a personal history. Pages 11-25 in C. R. Allen, and A. S. Garmestani, editors. 2015. Adaptive management of socialecological systems. Springer, Dordrecht, Netherlands. http://dx. doi.org/10.1007/978-94-017-9682-8 2

Huang, Y., R. K. Glicksman, C. O'Neill, W. L. Andreen, V. Flatt, W. Funk, R. K. Craig, A. Kaswan, and R. R. M. Verchick. 2011. Climate change and the Puget Sound: building the legal framework for adaptation. Climate Law 2(3):299-344. http://dx. doi.org/10.3233/CL-2011-039

Huitema, D., E. Mostert, W. Egas, S. Moellenkamp, C. PahlWostl, and R. Yalcin. 2009. Adaptive water governance: assessing the institutional prescriptions of adaptive (co-) management from a governance perspective and defining a research agenda. Ecology and Society 14(1):26. http://dx.doi.org/10.5751/ES-02827-140126

Humby, T.-L. 2014. Law and resilience: mapping the literature. Seattle Journal of Environmental Law 4(1):85-130. [online] URL: https://digitalcommons.law.seattleu.edu/sjel/vol4/iss1/4

Iles, A. T. 1996. Adaptive management: making environmental law and policy more dynamic, experimentalist and learning. Environmental and Planning Law Journal 13(4):288-308.

Jacobson, C., R. W. Carter, D. C. Thomsen, and T. F. Smith. 2014. Monitoring and evaluation for adaptive coastal management. Ocean and Coastal Management 89:51-57. http://dx.doi. org/10.1016/j.ocecoaman.2013.12.008

Jacobson, C., K. F. D. Hughey, W. J. Allen, S. Rixecker, and R. W. Carter. 2009. Toward more reflexive use of adaptive management. Society and Natural Resources 22(5):484-495. http://dx.doi.org/10.1080/08941920902762321

Jaeckel, A. 2016. Deep seabed mining and adaptive management: the procedural challenges for the International Seabed Authority. Marine Policy 70:205-211. http://dx.doi.org/10.1016/j.marpol.2016.03.008

Jantarasami, L. C., J. J. Lawler, and C. W. Thomas. 2010. Institutional barriers to climate change adaptation in U.S. national parks and forests. Ecology and Society 15(4):33. http:// dx.doi.org/10.5751/ES-03715-150433

Johnson, A., J. Goodrich, T. Hansel, A. Rasphone, S. Saypanya, C. Vongkhamheng, Venevongphet, and S. Strindberg. 2016. To protect or neglect? Design, monitoring, and evaluation of a law enforcement strategy to recover small populations of wild tigers and their prey. Biological Conservation 202:99-109. http://dx.doi. org/10.1016/j.biocon.2016.08.018
Jones, J. 2007. Regulatory design for scientific uncertainty: acknowledging the diversity of approaches in environmental regulation and public administration. Journal of Environmental Law 19(3):347-365. http://dx.doi.org/10.1093/jel/eqm023

Justiss, L. K. 2011. A survey of electronic research alternatives to LexisNexis and Westlaw in law firms. Law Library Journal 103 (1):71-89. [online] URL: https://ssrn.com/abstract=1649471

Karkkainen, B. C. 2005. Panarchy and adaptive change: around the loop and back again. Minnesota Journal of Law, Science and Technology 7(1):59-77. [online] URL: http://scholarship.law.umn. edu/mjlst/vol7/iss $1 / 6$

Karpouzoglou, T., A. Dewulf, and J. Clark. 2016. Advancing adaptive governance of social-ecological systems through theoretical multiplicity. Environmental Science and Policy 57:1-9. http://dx.doi.org/10.1016/j.envsci.2015.11.011

Koontz, T. M., and J. Bodine. 2008. Implementing ecosystem management in public agencies: lessons from the U.S. Bureau of Land Management and the Forest Service. Conservation Biology 22(1):60-69. http://dx.doi.org/10.1111/j.1523-1739.2007.00860.x

Kwasniak, A. J. 2010. Use and abuse of adaptive management in environmental law and practice: a Canadian example and general lessons. Journal of Environmental Assessment Policy and Management 12(4):425-468. http://dx.doi.org/10.1142/ $\underline{\mathrm{S} 1464333210003723}$

Lee, J. 2014. Theory to practice: adaptive management of the groundwater impacts of Australian mining projects. Environmental and Planning Law Journal 31(4):251-287.

Lee, K. N. 1999. Appraising adaptive management. Conservation Ecology 3(2):3. http://dx.doi.org/10.5751/ES-00131-030203

McCormack, P., and J. McDonald. 2014. Adaptation strategies for biodiversity conservation: Has Australian law got what it takes? Environmental and Planning Law Journal 31(2):114-136.

McDonald, J., P. C. McCormack, and A. Foerster. 2016. Promoting resilience to climate change in Australian conservation law: the case of biodiversity offsets. University of New South Wales Law Journal 39(4):1612-1651. [online] URL: http://www. unswlawjournal.unsw.edu.au/article/promoting-resilience-to-climatechange-in-australian-conservation-law-the-case-of-biodiversity-offsets/

McDonald, J., and M. C. Styles. 2014. Legal strategies for adaptive management under climate change. Journal of Environmental Law 26(1):25-53. http://dx.doi.org/10.1093/jel/equ003

McFadden, J. E., T. L. Hiller, and A. J. Tyre. 2011. Evaluating the efficacy of adaptive management approaches: is there a formula for success? Journal of Environmental Management 92 (5):1354-1359. http://dx.doi.org/10.1016/j.jenvman.2010.10.038

Meretsky, V. J., and R. L. Fischman. 2014. Learning from conservation planning for the U.S. National Wildlife Refuges. Conservation Biology 28(5):1415-1427. http://dx.doi.org/10.1111/ cobi.12292

Miles, M. B., and A. M. Huberman. 1994. Qualitative data analysis: an expanded source book. Second edition. Sage, Thousand Oaks, California, USA.

Milly, P. C. D., J. Betancourt, M. Falkenmark, R. M. Hirsch, Z. W. Kundzewicz, D. P. Lettenmaier, and R. J. Stouffer. 2008. 
Stationarity is dead: whither water management? Science 319 (5863):573-574. http://dx.doi.org/10.1126/science.1151915

Moher, D., A. Liberati, J. Tetzlaff, D. G. Altman, and the PRISMA Group. 2009. Preferred reporting items for systematic reviews and meta-analyses: the PRISMA statement. PLoS Medicine 6(7):e1000097. http://dx.doi.org/10.1371/journal.pmed.1000097

Moore, M.-L., S. von der Porten, R. Plummer, O. Brandes, and J. Baird. 2014. Water policy reform and innovation: a systematic review. Environmental Science and Policy 38:263-271. http://dx. doi.org/10.1016/j.envsci.2014.01.007

Nie, M. A., and C. A. Schultz. 2012. Decision-making triggers in adaptive management. Conservation Biology 26(6):1137-1144. http://dx.doi.org/10.1111/j.1523-1739.2012.01915.x

Novellie, P., H. Biggs, and D. Roux. 2016. National laws and policies can enable or confound adaptive governance: examples from South African national parks. Environmental Science and Policy 66:40-46. http://dx.doi.org/10.1016/j.envsci.2016.08.005

Parlee, C. E., and M. G. Wiber. 2014. Institutional innovation in fisheries governance: adaptive co-management in situations of legal pluralism. Current Opinion in Environmental Sustainability 11:48-54. http://dx.doi.org/10.1016/j.cosust.2014.09.012

Patton, M. Q. 2002. Qualitative research and evaluation methods. Third edition. Sage, Thousand Oaks, California, USA.

Pickering, C., and J. A. Byrne. 2014. The benefits of publishing systematic quantitative literature reviews for $\mathrm{PhD}$ candidates and other early-career researchers. Higher Education Research and Development 33(3):534-548. http://dx.doi.org/10.1080/07294360.2013 .841651

Pidot, J. R. 2015. Governance and uncertainty. Cardozo Law Review 37(1):113-184. [online] URL: http://www.cardozolawreview. com/content/37-1/PIDOT.37.1.pdf

Plummer, R., B. Crona, D. Armitage, P. Olsson, M. Tengö, and O. Yudina. 2012b. Adaptive comanagement: a systematic review and analysis. Ecology and Society 17(3):11. http://dx.doi. org/10.5751/ES-04952-170311

Plummer, R., R. de Loë, and D. Armitage. 2012a. A systematic review of water vulnerability assessment tools. Water Resources Management 26(15):4327-4346. http://dx.doi.org/10.1007/ s11269-012-0147-5

Pratt Miles, J. D. 2013. Designing collaborative processes for adaptive management: four structures for multistakeholder collaboration. Ecology and Society 18(4):5. http://dx.doi. org/10.5751/ES-05709-180405

Preston, B. J. 2013. Adapting to the impacts of climate change: the limits and opportunities of law in conserving biodiversity. Environmental and Planning Law Journal 30(5):375-389.

Raadgever, G. T., E. Mostert,, N. Kranz, E. Interwies, and J. G. Timmerman. 2008. Assessing management regimes in transboundary river basins: do they support adaptive management? Ecology and Society 13(1):14. http://dx.doi. org/10.5751/ES-02385-130114

Richards, L. 1999. Using NVivo in qualitative research. Sage, Thousand Oaks, California, USA.
Ruhl, J. B. 2005. Regulation by adaptive management - is it possible? Minnesota Journal of Law, Science and Technology 7 (1):21-57. [online] URL: https://scholarship.law.umn.edu/mjlst/ vol7/iss $1 / 5 /$

Ruhl, J. B. 2011. General design principles for resilience and adaptive capacity in legal systems - with applications to climate change adaptation. North Carolina Law Review 89(5):1373-1404. [online] URL: http://scholarship.law.unc.edu/nclr/vol89/iss5/3/

Ruhl, J. B. 2012. Panarchy and the law. Ecology and Society 17 (3):31. http://dx.doi.org/10.5751/ES-05109-170331

Ruhl, J. B. 2016. Adaptive management of ecosystem services across different land use regimes. Journal of Environmental Management 183(2):418-423. http://dx.doi.org/10.1016/j. jenvman.2016.07.066

Ruhl, J. B., and R. L. Fischman. 2010. Adaptive management in the courts. Minnesota Law Review 95(2):424-484. [online] URL: http://www.minnesotalawreview.org/wp-content/uploads/2011/07/ Ruhl-Fischman_MLR.pdf

Schramm, D., and A. Fishman. 2010. Legal frameworks for adaptive natural resource management in a changing climate. Georgetown International Environmental Law Review 22 (3):491-520.

Schreiber, M. A. 2012. The evolution of legal instruments and the sustainability of the Peruvian anchovy fishery. Marine Policy 36 (1):78-89. http://dx.doi.org/10.1016/j.marpol.2011.03.010

Schultz, C. 2008. Responding to scientific uncertainty in U.S. forest policy. Environmental Science and Policy 11(3):253-271. http://dx.doi.org/10.1016/j.envsci.2007.09.002

Schultz, C., and M. Nie. 2012. Decision-making triggers, adaptive management, and natural resources law and planning. Natural Resources Journal 52(2):443-521. [online] URL: http:// digitalrepository.unm.edu/nrj/vol52/iss $2 / 8$

Smith, T. F., and N. S. Lazarow. 2006. Social learning and the adaptive management framework. Journal of Coastal Research Special Issue 39 (Proceedings of the 8th International Coastal Symposium):952-954.

Smith, T. F., and D. C. Smith. 2006. Institutionalizing adaptive learning for coastal management. Pages 101-106 in N. S. Lazarow, R. Souter, R. Fearon, and S. Dovers, editors. Coastal management in Australia: key institutional and governance issues for coastal natural resource management and planning. Cooperative Research Centre (CRC) for Coastal Zone, Estuary and Waterway Management, Indooroopilly, Queensland, Australia.

Spies, T. A., T. W. Giesen, F. J. Swanson, J. F. Franklin, D. Lach, and K. N. Johnson. 2010. Climate change adaptation strategies for federal forests of the Pacific Northwest, USA: ecological, policy, and socio-economic perspectives. Landscape Ecology 25 (8):1185-1199. http://dx.doi.org/10.1007/s10980-010-9483-0

Stankey, G. H., R. N. Clark, and B. T. Bormann. 2005. Adaptive management of natural resources: theory, concepts, and management institutions. General Technical Report PNWGTR-654. U.S. Forest Service, Pacific Northwest Research Station, Portland, Oregon. USA. http://dx.doi.org/10.2737/ PNW-GTR-654 
Steven, R., C. Pickering, and J. G. Castley. 2011. A review of the impacts of nature based recreation on birds. Journal of Environmental Management 92(10):2287-2294. http://dx.doi. org/10.1016/j.jenvman.2011.05.005

Stuart-Hill, S. I., and R. E. Schulze. 2010. Does South Africa's water law and policy allow for climate change adaptation? Climate and Development 2(2):128-144. http://dx.doi.org/10.3763/cdev.2010.0035

Tan, P. L., D. George, and M. Comino. 2015. Cumulative risk management, coal seam gas, sustainable water, and agriculture in Australia. International Journal of Water Resources Development 31(4):682-700. http://dx.doi.org/10.1080/07900627.2014.994593

Thrower, J. 2006. Adaptive management and NEPA: how a nonequilibrium view of ecosystems mandates flexible regulation. Ecology Law Quarterly 33(3):871-896. http://dx.doi.org/10.15779/ Z38T83K

Van Buuren, A., A. M. Keessen, C. van Leeuwen, J. Eshuis, and G. J. Ellen. 2015. Implementation arrangements for climate adaptation in the Netherlands: characteristics and underlying mechanisms of adaptive governance. Ecology and Society 20 (4):11. http://dx.doi.org/10.5751/ES-07704-200411

Van Rijswick, M., and W. Salet. 2012. Enabling the contextualization of legal rules in responsive strategies to climate change. Ecology and Society 17(2):18. http://dx.doi.org/10.5751/ ES-04895-170218

West, S. P., and L. Schultz. 2015. Learning for resilience in the European Court of Human Rights: adjudication as an adaptive governance practice. Ecology and Society 20(1):31. http://dx.doi. org/10.5751/ES-07190-200131

Westgate, M. J., G. E. Likens, and D. B. Lindenmayer. 2013. Adaptive management of biological systems: a review. Biological Conservation 158:128-139. http://dx.doi.org/10.1016/j.biocon.2012.08.016

Wiafe, E. D. 2016. Wildlife laws monitoring as an adaptive management tool in protected area management in Ghana: a case of Kakum Conservation Area. SpringerPlus 5:1440. http://dx.doi. org/10.1186/s40064-016-3129-X

Williams, B. K. 2011. Adaptive management of natural resources -framework and issues. Journal of Environmental Management 92(5):1346-1353. http://dx.doi.org/10.1016/j.jenvman.2010.10.041

Williams, B. K., and E. D. Brown. 2014. Adaptive management: from more talk to real action. Environmental Management 53 (2):465-479. http://dx.doi.org/10.1007/s00267-013-0205-7

Williams, B. K., and E. D. Brown. 2016. Technical challenges in the application of adaptive management. Biological Conservation 195:255-263. http://dx.doi.org/10.1016/j.biocon.2016.01.012

Zellmer, S., and L. Gunderson. 2008. Why resilience may not always be a good thing: lessons in ecosystem restoration from Glen Canyon and the Everglades. Nebraska Law Review 87 (4):893-949. [online] URL: https://digitalcommons.unl.edu/nlr/ vol $87 /$ iss $4 / 2 /$ 
Appendix 1. Literature Sample

\begin{tabular}{|c|c|c|c|c|c|}
\hline & Author/year & Journal & Geographical Context & $\begin{array}{l}\text { Main Environmental } \\
\text { Sector or Concern }\end{array}$ & $\begin{array}{l}\text { Interviews } \\
\text { or Surveys }\end{array}$ \\
\hline 1 & Thrower (2006) & Ecology Law Quarterly & USA & Multiple & No \\
\hline 2 & Angelo (2006) & Ecology Law Quaterly & USA & Biodiversity & No \\
\hline 3 & Jones (2007) & $\begin{array}{l}\text { Journal of } \\
\text { Environmental Law }\end{array}$ & $\begin{array}{l}\text { USA } \\
\text { Australia }\end{array}$ & Multiple & No \\
\hline 4 & $\begin{array}{l}\text { Koontz and Bodine } \\
(2008)\end{array}$ & Conservation Biology & USA & Multiple & Yes \\
\hline 5 & $\begin{array}{l}\text { Garmestani et al. } \\
(2008)\end{array}$ & Nebraska Law Review & USA & Multiple & No \\
\hline 6 & Schultz (2008) & $\begin{array}{l}\text { Environmental Science } \\
\text { and Policy }\end{array}$ & USA & $\begin{array}{l}\text { Forestry/Protected } \\
\text { Areas }\end{array}$ & No \\
\hline 7 & $\begin{array}{l}\text { Raadgever et al. } \\
\text { (2008) }\end{array}$ & Ecology and Society & Multiple & Water & Yes \\
\hline 8 & $\begin{array}{l}\text { Zellmer and } \\
\text { Gunderson (2008) }\end{array}$ & Nebraska Law Review & USA & Multiple & No \\
\hline 9 & Angelo (2008) & Nebraska Law Review & USA & Multiple & No \\
\hline 10 & Spies et al. (2010) & Landscape Ecology & USA & $\begin{array}{l}\text { Forestry/Protected } \\
\text { Areas }\end{array}$ & No \\
\hline 11 & Craig (2010a) & Vermont Law Review & USA & Water & No \\
\hline 12 & Craig (2010b) & $\begin{array}{l}\text { Havard Environmental } \\
\text { Law Review }\end{array}$ & USA & Multiple & No \\
\hline 13 & $\begin{array}{l}\text { Stuart-Hill and } \\
\text { Schulze (2010) }\end{array}$ & $\begin{array}{l}\text { Climate and } \\
\text { Development }\end{array}$ & South Africa & Water & No \\
\hline 14 & $\begin{array}{l}\text { Jantarasami et al. } \\
(2010)\end{array}$ & Ecology and Society & USA & $\begin{array}{l}\text { Forestry/Protected } \\
\text { Areas }\end{array}$ & Yes \\
\hline 15 & Kwasniak (2010) & $\begin{array}{l}\text { Journal of } \\
\text { Environmental } \\
\text { Assessment Policy and } \\
\text { Management } \\
\end{array}$ & Canada & Multiple & No \\
\hline 16 & $\begin{array}{l}\text { Ruhl and Fischman } \\
(2010)\end{array}$ & Minnesota Law Review & USA & Multiple & No \\
\hline 17 & $\begin{array}{l}\text { Schramm and } \\
\text { Fischman (2010) }\end{array}$ & Minnesota Law Review & Multiple & Multiple & No \\
\hline 18 & $\begin{array}{l}\text { Godden and Kung } \\
\text { (2011) }\end{array}$ & $\begin{array}{l}\text { Water Resources } \\
\text { Management }\end{array}$ & Australia & Water & No \\
\hline 19 & Dwyer (2011) & $\begin{array}{l}\text { Macquarie Journal of } \\
\text { International and } \\
\text { Comparative } \\
\text { Environmental Law }\end{array}$ & Australia & Multiple & No \\
\hline 20 & $\begin{array}{l}\text { Benson and } \\
\text { Garmestani (2011) }\end{array}$ & $\begin{array}{l}\text { Journal of } \\
\text { Environmental } \\
\text { Management }\end{array}$ & USA & Multiple & No \\
\hline 21 & $\begin{array}{l}\text { Holley and Sinclair } \\
\text { (2011) }\end{array}$ & $\begin{array}{l}\text { The Australasian } \\
\text { Journal of Natural } \\
\text { Resources Law and } \\
\text { Policy }\end{array}$ & Australia & Water & Yes \\
\hline 22 & Huang et al. (2011) & Climate Law & USA & Multiple & No \\
\hline 23 & Biber (2011) & $\begin{array}{l}\text { University of Colorado } \\
\text { Law Review }\end{array}$ & USA & Multiple & No \\
\hline 24 & Ruhl (2011) & $\begin{array}{l}\text { The North Carolina } \\
\text { Law Review }\end{array}$ & USA & Multiple & No \\
\hline
\end{tabular}




\begin{tabular}{|c|c|c|c|c|c|}
\hline 25 & $\begin{array}{l}\text { van Rijswick and } \\
\text { Salet (2012) }\end{array}$ & Ecology and Society & USA & Multiple & No \\
\hline 26 & Ruhl (2012) & Ecology and Society & USA & Multiple & No \\
\hline 27 & $\begin{array}{l}\text { Schultz and Nie } \\
\text { (2012) }\end{array}$ & $\begin{array}{l}\text { The Natural Resources } \\
\text { Journal }\end{array}$ & USA & Multiple & No \\
\hline 28 & $\begin{array}{l}\text { Nie and Schultz } \\
(2012)\end{array}$ & Conservation Biology & USA & Multiple & No \\
\hline 29 & $\begin{array}{l}\text { Herrfahrdt-Pähle } \\
\text { and Pahl-Wostl } \\
\text { (2012) }\end{array}$ & Ecology and Society & $\begin{array}{l}\text { South Africa } \\
\text { Uzbekistan }\end{array}$ & Water & Yes \\
\hline 30 & $\begin{array}{l}\text { Green and } \\
\text { Garmestani (2012) }\end{array}$ & Diversity & USA & Biodiversity & No \\
\hline 31 & Benson (2012) & Ecology and Society & USA & Biodiversity & No \\
\hline 32 & Schreiber (2012) & Marine Policy & Peru & Fisheries & No \\
\hline 33 & Chapman (2012) & $\begin{array}{l}\text { Science of the Total } \\
\text { Environment }\end{array}$ & USA & Multiple & No \\
\hline 34 & $\begin{array}{l}\text { Cosens and } \\
\text { Williams (2012) }\end{array}$ & Ecology and Society & USA & Multiple & No \\
\hline 35 & Bjorkland (2013) & $\begin{array}{l}\text { Environmental Impact } \\
\text { Assessment Review }\end{array}$ & USA & Multiple & No \\
\hline 36 & Preston (2013) & $\begin{array}{l}\text { Environmental and } \\
\text { Planning Law Journal }\end{array}$ & Australia & Biodiversity & No \\
\hline 37 & $\begin{array}{l}\text { Benson and Stone } \\
(2013)\end{array}$ & Ecology and Society & USA & Multiple & Yes \\
\hline 38 & Green et al. (2013) & Ecology and Society & Multiple & Water & No \\
\hline 39 & $\begin{array}{l}\text { Garmestani and } \\
\text { Benson (2013) }\end{array}$ & Ecology and Society & USA & Marine/Coastal & No \\
\hline 40 & Cosens (2013) & Ecology and Society & USA & Multiple & No \\
\hline 41 & Benson et al. (2013) & Ecology and Society & USA & Water & No \\
\hline 42 & Pratt Miles (2013) & Ecology and Society & USA & Multiple & No \\
\hline 43 & Biber (2013) & Akron Law Review & USA & Multiple & No \\
\hline 44 & Demange (2013) & $\begin{array}{l}\text { Pace Environmental } \\
\text { Law Review }\end{array}$ & Multiple & Multiple & No \\
\hline 45 & $\begin{array}{l}\text { McDonald and } \\
\text { Styles (2014) }\end{array}$ & $\begin{array}{l}\text { Journal of } \\
\text { Environmental Law }\end{array}$ & Multiple & Multiple & No \\
\hline 46 & Cosens et al. (2014) & Sustainability & USA & Water & No \\
\hline 47 & $\begin{array}{l}\text { Chaffin et al. } \\
(2014)\end{array}$ & Ecology and Society & USA & Multiple & No \\
\hline 48 & $\begin{array}{l}\text { Craig and Ruhl } \\
\text { (2014) }\end{array}$ & $\begin{array}{l}\text { Vanderbilt Law } \\
\text { Review }\end{array}$ & USA & Multiple & No \\
\hline 49 & Garmestani (2014) & $\begin{array}{l}\text { Clean Technologies } \\
\text { and Environmental } \\
\text { Policy }\end{array}$ & USA & Multiple & No \\
\hline 50 & He (2014) & $\begin{array}{l}\text { Asia Pacific Journal of } \\
\text { Environmental Law }\end{array}$ & China & Multiple & No \\
\hline 51 & $\begin{array}{l}\text { McCormack and } \\
\text { McDonald (2014) }\end{array}$ & $\begin{array}{l}\text { Environmental and } \\
\text { Planning Law Journal }\end{array}$ & Australia & Biodiversity & No \\
\hline 52 & $\begin{array}{l}\text { Meretsky and } \\
\text { Fischman (2014) }\end{array}$ & Conservation Biology & USA & $\begin{array}{l}\text { Forestry/Protected } \\
\text { Areas }\end{array}$ & No \\
\hline 53 & $\begin{array}{l}\text { Parlee and Wiber } \\
\text { (2014) }\end{array}$ & $\begin{array}{l}\text { Current Opinion in } \\
\text { Environmental } \\
\text { Sustainability }\end{array}$ & Canada & Fisheries & Yes \\
\hline 54 & Biber (2014) & Idaho Law Review & USA & Multiple & No \\
\hline 55 & Arnold (2014) & $\begin{array}{l}\text { The University of } \\
\text { Kansas Law Review }\end{array}$ & USA & Water & No \\
\hline 56 & Humby (2014) & $\begin{array}{l}\text { The Seattle Journal of } \\
\text { Environmental Law }\end{array}$ & USA & Multiple & No \\
\hline
\end{tabular}




\begin{tabular}{|c|c|c|c|c|c|}
\hline 57 & Borgström (2015) & $\begin{array}{l}\text { Review of European } \\
\text { Community and } \\
\text { International } \\
\text { Environmental Law }\end{array}$ & Finland & Biodiversity & No \\
\hline 58 & Butler et al. (2015) & $\begin{array}{l}\text { Environmental } \\
\text { Management }\end{array}$ & USA & $\begin{array}{l}\text { Forestry/Protected } \\
\text { Areas }\end{array}$ & Yes \\
\hline 59 & Green et al. (2015) & $\begin{array}{l}\text { Frontiers in Ecology } \\
\text { and the Environment }\end{array}$ & USA & Multiple & No \\
\hline 60 & Tan et al. (2015) & $\begin{array}{l}\text { International Journal of } \\
\text { Water Resources } \\
\text { Development }\end{array}$ & Australia & Water & No \\
\hline 61 & $\begin{array}{l}\text { Van Buuren et al. } \\
(2015)\end{array}$ & Ecology and Society & Netherlands & Water & Yes \\
\hline 62 & $\begin{array}{l}\text { West and Schultz } \\
\text { (2015) }\end{array}$ & Ecology and Society & Multiple & Multiple & No \\
\hline 63 & Pidot (2015) & Cardozo Law Review & USA & Multiple & No \\
\hline 64 & Arnold (2015) & $\begin{array}{l}\text { Journal of } \\
\text { Environmental and } \\
\text { Sustainability Law }\end{array}$ & USA & Water & No \\
\hline 65 & Wiafe (2016) & Springer Plus & Ghana & Biodiversity & No \\
\hline 66 & Ruhl (2016) & $\begin{array}{l}\text { Journal of } \\
\text { Environmental } \\
\text { Management }\end{array}$ & USA & Multiple & No \\
\hline 67 & $\begin{array}{l}\text { Novellie et al. } \\
(2016)\end{array}$ & $\begin{array}{l}\text { Environmental Science } \\
\text { and Policy }\end{array}$ & South Africa & $\begin{array}{l}\text { Forestry/Protected } \\
\text { Areas }\end{array}$ & No \\
\hline 68 & $\begin{array}{l}\text { Johnson et al. } \\
\text { (2016) }\end{array}$ & $\begin{array}{l}\text { Biological } \\
\text { Conservation }\end{array}$ & Laos & Biodiversity & No \\
\hline 69 & Jaeckel (2016) & Marine Policy & Australia & Marine/Coastal & No \\
\hline 70 & Garner (2016) & Water International & USA & Water & No \\
\hline 71 & $\begin{array}{l}\text { Fuentes et al. } \\
\text { (2016) }\end{array}$ & $\begin{array}{l}\text { Mitigation and } \\
\text { Adaptation Strategies } \\
\text { for Global Change }\end{array}$ & Australia & Biodiversity & No \\
\hline 72 & Frost et al. (2016) & $\begin{array}{l}\text { Aquatic Conservation: } \\
\text { Marine and Freshwater } \\
\text { Ecosystems }\end{array}$ & United Kingdom & Biodiversity & No \\
\hline 73 & $\begin{array}{l}\text { Fischman and Ruhl } \\
\text { (2016) }\end{array}$ & Conservation Biology & USA & Multiple & No \\
\hline 74 & $\begin{array}{l}\text { Cosens and Chaffin } \\
(2016)\end{array}$ & Water & USA & Water & No \\
\hline 75 & Cheng et al. (2016) & Journal of Forestry & USA & $\begin{array}{l}\text { Forestry/Protected } \\
\text { Areas }\end{array}$ & Yes \\
\hline 76 & $\begin{array}{l}\text { Chaffin et al. } \\
\text { (2016) }\end{array}$ & $\begin{array}{l}\text { Journal of } \\
\text { Environmental } \\
\text { Management }\end{array}$ & USA & Water & No \\
\hline 77 & $\begin{array}{l}\text { Curran and Masche } \\
\text { (2016) }\end{array}$ & $\begin{array}{l}\text { McGill Journal of } \\
\text { Sustainable } \\
\text { Development Law }\end{array}$ & $\begin{array}{l}\text { Australia } \\
\text { Canada }\end{array}$ & Water & No \\
\hline 78 & $\begin{array}{l}\text { Biber and Eagle } \\
\text { (2016) }\end{array}$ & Ecology Law Quarterly & USA & Multiple & No \\
\hline 79 & $\begin{array}{l}\text { McDonald et al. } \\
\text { (2016) }\end{array}$ & $\begin{array}{l}\text { University of New } \\
\text { South Wales Law } \\
\text { Journal }\end{array}$ & Australia & Biodiversity & Yes \\
\hline 80 & $\begin{array}{l}\text { Camacho and } \\
\text { Gliksman (2016) }\end{array}$ & Water International & USA & Water & No \\
\hline
\end{tabular}

